\title{
Seroprevalence in Tamil Nadu through India's two COVID waves: Evidence on antibody decline following infection and vaccination
}

\author{
Selvavinayagam T.S., Somasundaram A., Jerard Maria Selvam, \\ Sabareesh Ramachandran, Sampath P., Vijayalakshmi V., Ajith Brabhu Kumar C., \\ Sudharshini Subramaniam, Raju. S, Avudaiselvi. R, Prakash V., Yogananth N., \\ Gurunathan Subramanian, Roshini A, Dhiliban D.N., Sofia Imad, Vaidehi Tandel, \\ Rajeswari Parasa, Stuti Sachdeva, Anup Malani*
}

\begin{abstract}
Three rounds of population-representative serological studies through India's two COVID waves (round 1, 19 October-30 November 2020; round 2, 7-30 April 2021; and round 3, 28 June-7 July7, 2021) were conducted at the district-level in Tamil Nadu state (population 72 million). State-level seroprevalence in rounds 1,2 and 3 were $31.5 \%, 22.9 \%$, and $67.1 \%$. Estimated seroprevalence implies that at least 22.6 and 48.1 million persons were infected by the 30 November 2020 and 7 July 2021. There was substantial variation across districts in the state in each round. Seroprevalence ranged from 11.1 to $49.8 \%$ (round 1), 7.9 to $50.3 \%$ (round 2), and 37.8 to $84 \%$ (round 3). Seroprevalence in urban areas was higher than in rural areas (35.7 v. $25.7 \%$ in round $1,74.8 \%$ v. $64.1 \%$ in round 3 ). Females had similar seroprevalence to males (30.8 v. $30.2 \%$ in round $1,67.5$ v. $65.5 \%$ in round 3 ). While working age populations (age $40-49$ : $31.6 \%$ ) had significantly higher seroprevalence than the youth (age 18-29: 30.4\%) or elderly (age $70+: 26.5 \%$ ) in round 1, only the gap between working age (age 40-49: 66.7\%) and elderly (age 70+: 59.6\%) remained significant in round 3. Seroprevalence was greater among those who were vaccinated for COVID ( $25.7 \%$ v. $20.9 \%$ in round $2,80.0 \%$ v. $62.3 \%$ in round 3 ). While the decline in seroprevalence from round 1 to 2 suggests antibody decline after natural infection, we do not find significant decline in antibodies among those receiving at least 1 dose of vaccine between rounds 2 and 3 .
\end{abstract}

\section{Introduction}

Knowledge of population-level immunity is critical for understanding the epidemiology of SARSCoV-2 (COVID-19) and formulating effective infection control, including the allocation of scarce

\footnotetext{
${ }^{*}$ Directorate of Public Health \& Preventative Medicine, Government of Tamil Nadu: Selvavinayagam, T.S., Somasundaram A., Jerard Maria Selvam, Sampath P., Vijayalakshmi V., Ajith Brabhu Kumar C., Sudharshini Subramaniam, S. Raju, Avudaiselvi, Prakash V., Yogananth N., Roshini, and Dhilipan; University of California, San Diego: Sabareesh Ramachandran; IDFC Institute: Sofia Imad. Rajeshwari Parasa; independent: Vaidehi Tandel and Stuti Sachdeva; University of Chicago: Anup Malani. Corresponding author (amalani@uchicago.edu).
} 
vaccines. Tamil Nadu is the 6th most populous state in India, with roughly 72 million persons ${ }^{1}$. It has reported roughly 2.6 million COVID-19 cases and 35,000 deaths, ranked 4th and 3rd highest, respectively, among Indian states ${ }^{2}$. Reported cases are not, however, gathered from population-representative samples.

The state government conducted population-level seroprevalence surveys across all districts of the state (excluding Chennai) in 3 rounds, in October-November 2020, April 2021, and June-July 2021. The state also conducted the surveys in Chennai district in rounds 1 and 3 . We report seroprevalence estimates from these surveys by district, by demographic groups, and by urban status. We compare the results of the surveys to estimates from reported cases to measure the degree to which reported cases underestimate population immunity. We also infer the extent to which antibodies decline following infection and vaccination by using data on changes in district-level seroprevalence across rounds and individual reports of the date of their own vaccination, respectively.

\section{Methods}

The study was approved by the Directorate of Public Health and Preventive Medicine, Government of Tamil Nadu, and the Institutional Ethics Committee of Madras Medical College, Chennai, India. The study was funded by the Government of Tamil Nadu and National Health Mission, Tamil Nadu.

Outcomes. The first primary endpoint of the study is the fraction of the population that would obtain positive results on CLIA (chemiluminescent immunoassay) antibody tests for COVID, i.e., seropositivity, at the district-level. The second primary endpoint is the fraction of the population that have antibodies for COVID, i.e., seroprevalence, district level.

There are multiple secondary endpoints. One set is seroprevalence (a) by age and sex, (b) by urban status, and (c) at the state level. A final secondary outcome is the difference between population immunity estimated by serological survey and by reported cases.

Sample and location. Individuals residing in Tamil Nadu and ages 18 years and older were eligible for this study. The exclusion criteria were refusal to consent and contraindication to venipuncture. In round 2, Chennai district was not surveyed.

Sample size. The state sought to sample roughly 300 persons per 1 million population based on the 2011 Indian Census. The state's population is organized into districts, districts into health unit districts (HUD), and HUDs into clusters, defined as streets in urban and habitations in rural 
areas. Within each cluster the study aimed to sample 30 individuals. This last number and the state-wide sample rate implied a target of 888 clusters to be sampled. Allocating clusters to district proportional to population, 123 of these clusters were in Chennai. In rounds 1 and 3 , this implied a target sample size of 26,640 persons; in round 2 , which excluded Chennai, the target was 22,950 persons.

Sample selection. The study selected participants within a HUD in three steps. First, within each HUD, the study randomly selected clusters. The fraction of all clusters picked from a HUD is equal to proportional to the HUD's population. Second, within each cluster, we selected a random GPS starting point. Third, we sampled one participant from households adjacent to that starting point until 30 persons consented within a cluster. Within each household, the member asked to provide a biosample was selected via the Kish method ${ }^{3}$. The study sampled participants using this process separately in each of the three rounds of survey; therefore, the participants sampled in each round may not be the same people sampled in other rounds.

Survey timing. Data was gathered between 19 October - 30 November 2020, 7 - 30 April 2021, and 28 June to 7 July 2021, in round 1, 2 and 3. In round 1, districts other than Chennai were sampled a few weeks before Chennai, from 19 October - 5 November 2020; Chennai was sampled 6 November - 30 November 2020.

Data collection. Each participant was asked to complete a health questionnaire and provide $5 \mathrm{ml}$ venous blood collected in EDTA vacutainers. Serum was analyzed for IgG antibodies to the SARS-CoV-2 spike protein using either the iFlash-SARS-CoV-2 IgG (Shenzhen YHLO Biotech; sensitivity of $95.9 \%$ and specificity of $95.7 \%$ per manufacturer) ${ }^{4}$ or the Vitros anti-SARS-CoV-2 IgG CLIA kit (Ortho-Clinical Diagnostics; sensitivity of $90 \%$ and specificity of $100 \%$ per manufacturer) ${ }^{5}$. Clusters were characterized as rural if they were in Census-defined villages. The government shared data on each reported COVID-19 case and death, including date and demographics. It also shared data on number of tests through December 2020.

Statistical analysis. The proportion of positive CLIA tests by district for a given round is obtained by estimating a weighted logit regression of test result on district indicators and reporting the inverse logit of the coefficient for each district indicator. Observations are weighted by the inverse of sampling probability for their age and gender groups; the sampling probability here and below is based on population counts from the 2011 Census. Standard errors calculated account for correlations at the cluster level.

The seroprevalence by district in a survey round is estimated in two steps. First, we calculate the weighted proportion of positive tests at the district level everywhere except Chennai in 
round 1 and Virudhunagar in round 3, where we calculate it at the health unit district (HUD), a subset of districts. All samples in a district were tested using the same type of CLIA kit, except in Chennai and Virudhunagar, where all samples in a HUD were tested with the same type of kit. We estimate a weighted logit regression of test results on district indicators outside Chennai and Virudhunagar and HUD indicators in Chennai and Virudhunagar and take the inverse logit of the coefficient for each jurisdiction indicator. Observations are weighted by the inverse of sampling probability for their age and gender groups. Clustered standard errors are calculated at the cluster level. Second, for each jurisdiction, we predict seroprevalence using the Rogan-Gladden formula, test parameters for the kit used in each jurisdiction, and regression estimates of seropositive proportion by jurisdiction. In Chennai and Virudhunagar districts, we calculate seroprevalence at the district level as a weighted average of seroprevalence at the HUD level, using as weights the share of clusters in each HUD. (We employ this approach to Chennai and Virudhunagar in the estimators below.)

Seroprevalence in the state in a round is obtained by aggregating the seroprevalence across districts weighted by 2011 census data on the relative populations of districts.

Seroprevalence by demographic group in a round is estimated in three steps. First, we calculate the proportion of positive tests at the jurisdiction-by-demographic group level in that round using logit regressions of test results on jurisdiction-by-demographic group indicators. Demographic groups indicators are sex $x$ age for 6 age bins. Standard errors are clustered at the cluster level. Second, we predict district-by-demographic group level seroprevalence using the Rogan-Gladden formula. Third, we compute the weighted average of seroprevalence at the demographic-group level using as weights the share of demographic-group population in each district using data from the 2011 Indian census.

Seroprevalence by vaccine status in each of rounds 2 and 3 (when vaccines were available) is estimated in the same manner we calculate seroprevalence by demographic group in a round, except we replace demographic group by vaccine status.

Seroprevalence by urban status in a round is obtained in the same manner as seroprevalence by demographic group, with two changes. First, we use the urban status of a cluster in lieu of demographic status of an individual at each step. Second, observations in our regression are weighted by inverse of the sampling probability for their urban status.

The size of a population that was previously infected by a round is obtained by multiplying our seroprevalence estimates for the population in that round by the size of that population (as reported in the 2011 Indian Census). 
The degree of undercounting of cases in a round is estimated by dividing the estimated number previously infected in the Tamil Nadu population by the number of officially reported cases in that population as of 1 week before the median sampling date. The median sampling rate is calculated at the state-level for rounds 2 and 3, but at the district-level for round 1 because that round took place over a longer period and some districts finished far before or after others (medians were 23 October 2020, 12 April 2021 and 1 July 2021 in rounds 1, 2 and 3, respectively). We obtain data on officially reported cases from the government of Tamil Nadu. The lag accounts for the delay, both between infection and seropositive status and between infection and prevalence testing. We calculate the Pearson's correlation coefficient between undercounting rate and testing rate (tests per million as of median date of testing) by district.

We estimate the decline of antibodies after infection and in the absence of vaccination using district-level observations and a linear regression of district-level seropositivity in round 2 on district-level seropositivity in round 1 . Observations are weighted in proportion to the population of each district in the 2011 Census. To address the possibility that decay is masked by new infections we estimate a second specification that includes in the regression a measure of the percent of population infected between round 1 and round 2; this measure, which we call the adjusted reported cases rate is the number of new confirmed cases per capita between rounds 1 and 2, adjusted by the infection undercount rate (seroprevalence rate in round 1 divided by cases per capita until round 1 ).

We estimate the decline of antibodies following one dose of vaccination in two steps. First, we restrict the sample to individuals from round 3 who had been vaccinated only with dose 1 and who had been vaccinated at least at least 20 days prior to biosample collection. We focus on individuals with just 1 dose because they are more in number and have greater variation in the number of days since vaccination; this variation exists because many people who received 1 dose had not got a second dose at the time of sample collection. The 20-day delay is intended to omit the period of time during which antibodies are climbing post-vaccination. We do not consider individuals from round 2 because we do not have their date of vaccination. Second, we estimate a linear regression with an indicator for whether a person was seropositive as the dependent variable and the number of days since vaccination as the independent variable. Observations are weighted to match age and gender proportions in the 2011 Census. To obtain plausibly causal estimates of antibody decline after vaccination, we use age as an instrumental variable for the number of days since vaccination. The logic for this instrument is that Tamil Nadu prioritized individuals for vaccination based on their age, with older age persons given greater priority; to validate this instrument, we create a binscatter of days since vaccination on age among individuals with only 1 dose of vaccine and confirm that days since vaccination rises 
with age. The drawback of this instrument is that it is possible that antibody decay is directly a function of age; therefore, the instrumental variables estimates should be taken with a grain of salt.

We document the level of positivity attributable to infection and to vaccination in three ways. First, we estimate the seroprevalence rate among individuals in round 3 conditional on the number of doses they have received. We calculate the incremental seroprevalence due to vaccination by taking the difference between (a) the seroprevalence with 1 or with 2 doses of vaccine and (b) the seroprevalence with no vaccination. We calculate the seroprevalence conditional on vaccination by taking the ratio of (a) the incremental seroprevalence due to vaccination and (b) the percent of the non-vaccinated population that was not seropositive due to infection.

Second, we create kernel density plots of serological values conditional on the number of doses and round. We do this separately for each type of test employed, as the scores from the CPC and the Ortho tests are not comparable.

Third, we examine the relationship between serological values and average seroprevalence. We compute the median serological test values for each kit at the state level among the vaccinated and seropositive individuals. We then compute the proportion of vaccinated and seropositive individuals in each district with an above median serological test value. This is plotted against the mean seroprevalence in the district. We also calculate the Pearson's correlation coefficient between serological test scores and mean seropositivity rate in a district.

Statistical tests comparing groups are performed using a two-sided Wald test with 95\%.

All statistical analyses were conducted with Microsoft Excel 365 (Microsoft, USA) and Stata 16 (StataCorp, USA). All plots were generated in R.

\section{Results}

In round 1, the study obtained lab results for 26,135 persons in 882 clusters. Six clusters, 1 of which was in Chennai, could not be sampled. One person aged 16 was incorrectly consented and dropped from the analysis in round 1 . The study was unable to consent or obtain lab results for 325 additional observations. In round 2, the study obtained results for 21,992 persons in 746 clusters. Chennai's allocation of 123 clusters was intentionally not sampled because of a sharp rise in cases in that district when sampling was intended to take place. Outside Chennai, 19 clusters could not be sampled. The study was unable to get consent or 
obtain lab results for 388 additional observations. In round 3 , the study obtained results for 26,592 persons. All clusters were sampled, but the study could not get consent or obtain lab results for 48 persons.

Table 1 reports the demographic characteristics of the sample in each round. The sample has substantially more females and fewer persons aged 18-29 and more elderly persons than the general population. We employ weights to rebalance the population breakdown to match the Census.

State level seroprevalence was 31.6\% (95\% Cl: 30.3-32.7\%) in round 1, 22.9\% (95\% Cl: $21.8-$ $23.9 \%)$ in round 2 , and $67.1 \%(95 \% \mathrm{Cl}: 65.9-68.3 \%)$ in round 3.

Seropositivity varies dramatically across districts, from $12.1 \%$ (The Nilgris) to $49.3 \%$ (Perambalur) in round 1, 11.1\% (Nagapattinam) to $49.1 \%$ (Tiruvallur) in round 2, and $36.8 \%$ (Erode) to $84.9 \%$ (Virudhunagar) in round 3 (Figure 1). Seroprevalence has a similar pattern to seropositivity (Figure 2).

Seroprevalence is significantly greater in urban areas than rural areas $(35.7 \%$ v. $25.7 \%, p<0.001$, in round $1 ; 74.8 \%$ v. $74.1 \%, p<0.001$, in round 3) (Table 2 ). Urban classification of clusters was not available for round 2 .

Seroprevalence is not significantly different across sexes (females v males: $30.8 \%$ v. $30.2 \%$ in round $1,22.0 \%$ v. $21.3 \%$ in round $2,67.5 \%$ v. $65.5 \%$ in round 3 ) (Table 2 ). Seroprevalence among the prime working age populations is significantly higher than among the elderly in rounds 1 and 3 (age 40-49 v. age 70+: 31.7\% v. 26.5\%, p<0.001 in round 1; 66.7\% v. 59.6\%, $p<0.001$ in round 3$)$. Seroprevalence among the older working age population is significantly greater than among younger populations in round 2 (50-59 v. 18-29: $25.6 \%$ v. 19.5\%, p<0.001) (Table 2).

Seroprevalence is significantly greater among vaccinated than unvaccinated populations ( $25.7 \%$ v. $20.9 \%, p<0.001$ in round $2 ; 80.0 \%$ v. $62.3 \%, p<0.001$ in round 3 ). Data from round 3 suggest that seroprevalence is increasing in number of doses taken ( 0 doses v. 1 dose, $62.3 \%$ v. $77.5 \%$, $\mathrm{p}<0.001 ; 1$ dose v. 2 doses, $77.5 \%$ v. $85.9 \%, p<0.001$ ) (Table 2 ).

The ratio of (a) the number of infection implied by seroprevalence to (b) confirmed cases ranges widely (from 10 to 148 in round 1, 12 to 69 in round 2, and 8 to 56 in round 3), but decline over rounds (Table 3 ). There is a negative and significant (round $1: \rho=-0.58, p<0.00$ ) correlation between testing rate and the undercount rate in round 1 (Figure 3 ). 
On average, district-wise seroprevalence rate in round 2 is at most $68.4 \%$ of the seroprevalence rate in round 1 in a district (Table 4). The 31.6\% decline in seroprevalence is an underestimate of antibody decline for two reasons. First, because at least $17.8 \%$ of sample members report being vaccinated with at least 1 dose. Second, individuals may have been infected between rounds 1 and 2 and that may trigger seropositivity in individuals who had no infection prior to round 1 or whose antibodies from a prior infection might otherwise have declined. Adding the per capita adjusted reported infection rate to the regression to control for the risk of infection yields a lower seropositivity rate of $37.4 \%$, implying a decline of $62.6 \%$.

The daily rate of antibody decay post vaccination among individuals given just 1 vaccine dose by round 3 is small and insignificant (Table 5). The rate remains small and insignificant even with the use of age as an instrumental variable for days since dose 1 to obtain causal estimates.

The seroprevalence rate among the unvaccinated in round 3 is $62.3 \%(60.0 \%$ in rural and $71.5 \%$ in urban areas). The seroprevalence rate among those with 1 dose is $77.5 \%$ (75.6\% in rural and $79.0 \%$ in urban areas) and with 2 doses is $85.9 \%$ ( $81.1 \%$ in rural and $80.8 \%$ in urban areas). (Seroprevalence in urban and rural subsamples can be lower than in the overall sample for dose-specific seroprevalence because we lack Census weights at the dose $x$ community type level.)

The serological scores of individuals with no vaccination have a single-peaked distribution with low mode in round 1 (mode $=10$ units in CPC kit) and round 3 (mode $=10$ units in CPC kit). The scores of those with vaccination have a bimodal distribution with peaks at 10 units and 400 units in CPC kit. Conditional on having at least 1 vaccine dose and being seropositive, an individual is more likely to have an above-median serological score if he/she is in a district with a higher round 3 overall seroprevalence rate (Figure 4). The Pearson correlation between the two is 0.5875 ( $p$-value $<0.001$ ).

\section{Discussion}

Overall seroprevalence implies that at least 22.6 million persons in Tamil Nadu were infected after Tamil Nadu's first wave (by 30 November 2020) and 48.2 million after Tamil Nadu's second wave (by July 7, 2021). The actual number of infections was roughly 35, 25 and 21 times larger than the number of confirmed cases in rounds 1,2 and 3, respectively $(674,802$, 896,226 , and 2,449,577 cases by 16 October 2020, 4 April 2021, and 24 June 2021) (www.covid19india.org). 
Antibody decline after infection affects how well prior seroprevalence measures prior infection rate. Consistent with this, we find that seropositivity declined between $31.6 \%$ and $62.6 \%$ over the roughly 6 months (170 days) between rounds 1 and 2 . We do not observe antibody decline following vaccination. However, we only observe individuals for roughly 3 months ( $95 \%$ of individuals with only 1 dose were vaccinated within 126 days). Therefore, we cannot rule out antibody decay following vaccination past 3 months. Moreover, vaccinated individuals may have experienced breakthrough infections during India's second wave and those infections may have caused antibodies to spike not due to vaccination alone.

The $67.1 \%$ seroprevalence rate after round 3 reflects both infections and vaccinations. The seropositivity rate among those who were not vaccinated by round 3 is $62.3 \%$. Assuming no selection into vaccinated status and that infection is independent of vaccination status, the incremental effect of vaccination on seropositivity is $15.2 \%$. Under the same assumptions, the seropositivity rate conditional on no infection is $40.3 \%$. The less-than- $100 \%$ seroprevalence rate among the vaccinated, combined with the lack of evidence of post-vaccination antibody decline, suggests some doses may have been ineffective at triggering a detectable antibody response, though we cannot be sure this is because some doses were not manufactured or preserved well or because the vaccines were not administered effectively.

The combination of vaccination and infection is associated with higher quantitative serological results. Individuals with no vaccination had a unimodal distribution of test scores with a low mode. Individuals with 1 and with 2 doses had a bimodal distribution with a lower mode the same as that of individuals with no vaccination. It is unlikely that 2 doses were responsible for the higher mode among those vaccinated. First, individuals with only 1 dose also had a higher mode. Second, the higher mode is positively and significantly correlated with infection risk, as measured by seropositivity rates at the district level.

It is unlikely that the Delta variant, which was responsible for a large percentage of infections in India's second wave $^{6}$, was responsible for above-median scores among those who are seropositive. The distribution of quantitative scores among the unvaccinated in round 1 , which was dominated by the wild strain 7 , has a similar shape and mode as the scores of the unvaccinated in round 3 .

Our study has several limitations. First, because antibody concentrations in infected persons decline over time ${ }^{8}$, our estimate of seroprevalence in round 1 may underestimate the level of prior infection and perhaps natural immunity. Our estimate of $31.6 \%$ seroprevalence in round 2 after adjusting for infections between rounds 1 and 2 may be incorrect if our adjusted reported case rate does not accurately estimate of those infections. The fact that a 1 
medRxiv preprint doi: https://doi.org/10.1101/2021.11.14.21265758; this version posted November 15, 2021. The copyright holder for this preprint (which was not certified by peer review) is the author/funder, who has granted medRxiv a license to display the preprint in perpetuity.

It is made available under a CC-BY 4.0 International license .

percentage point increase in that adjusted rate is associated with a 1 percentage point higher seropositivity rate suggests, however, that rate is a reasonable measure of infections.

Second, we may not accurately untangle seropositivity in round 3 that is due to infection versus due to vaccination. Seroprevalence among the unvaccinated during round 3 may not be a reasonable measure of seropositivity if people were not to be vaccinated if age or self-selection affects vaccination status. Our estimate of seroprevalence due to vaccination may be off if our adjusted reported case rate (over 30 days prior to vaccination) does not accurately estimate infection risk.

\section{Acknowledgments}

The study design and sampling was conceived, led and carried out by the Directorate of Public Health and Preventive Medicine, Government of Tamil Nadu, for the Government of Tamil Nadu's Department of Health and Family Welfare. Data cleaning was performed by V. Tandel and Rajeshwari Parasa. Statistical analysis was conducted by S. Ramachandran and A. Malani. Writing was done A. Malani, S. Ramachandran and S. Sachdeva. 
medRxiv preprint doi: https://doi.org/10.1101/2021.11.14.21265758; this version posted November 15, 2021. The copyright holder for this preprint (which was not certified by peer review) is the author/funder, who has granted medRxiv a license to display the preprint in perpetuity.

It is made available under a CC-BY 4.0 International license .

\section{Figures and tables}


medRxiv preprint doi: https://doi.org/10.1101/2021.11.14.21265758; this version posted November 15, 2021. The copyright holder for this preprint (which was not certified by peer review) is the author/funder, who has granted medRxiv a license to display the preprint in perpetuity.

It is made available under a CC-BY 4.0 International license .

Figure 1. Proportion of positive CLIA tests by district.
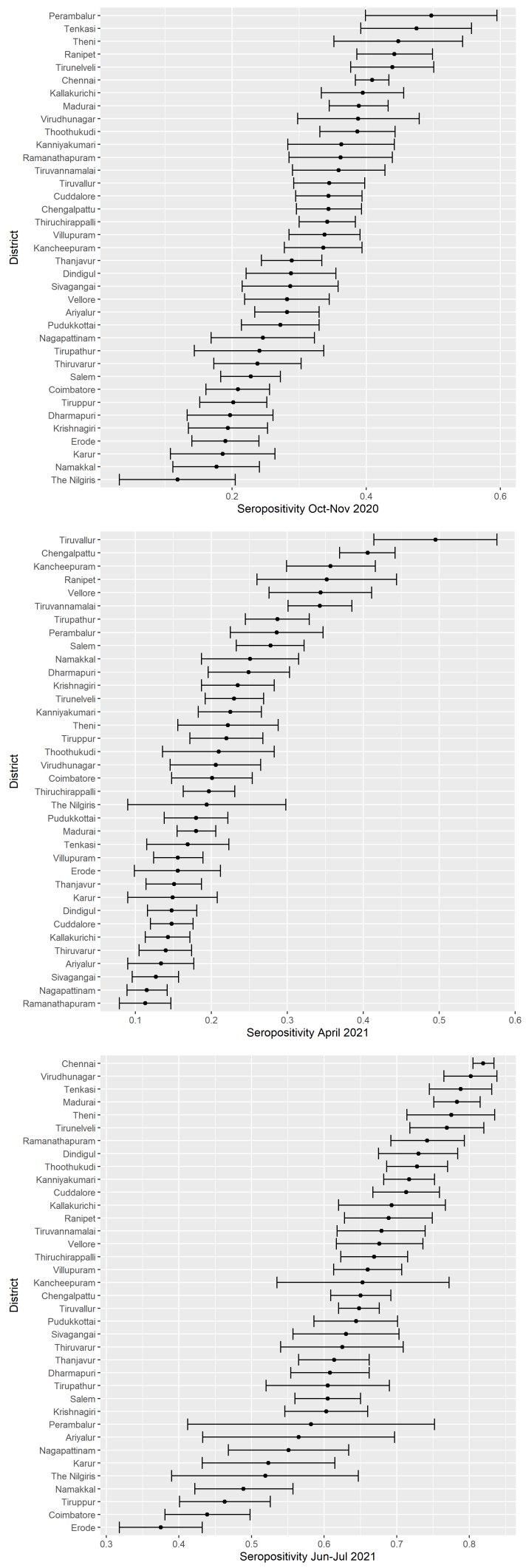
medRxiv preprint doi: https://doi.org/10.1101/2021.11.14.21265758; this version posted November 15, 2021. The copyright holder for this preprint (which was not certified by peer review) is the author/funder, who has granted medRxiv a license to display the preprint in perpetuity.

It is made available under a CC-BY 4.0 International license .

Figure 2. Seroprevalence by district and round.
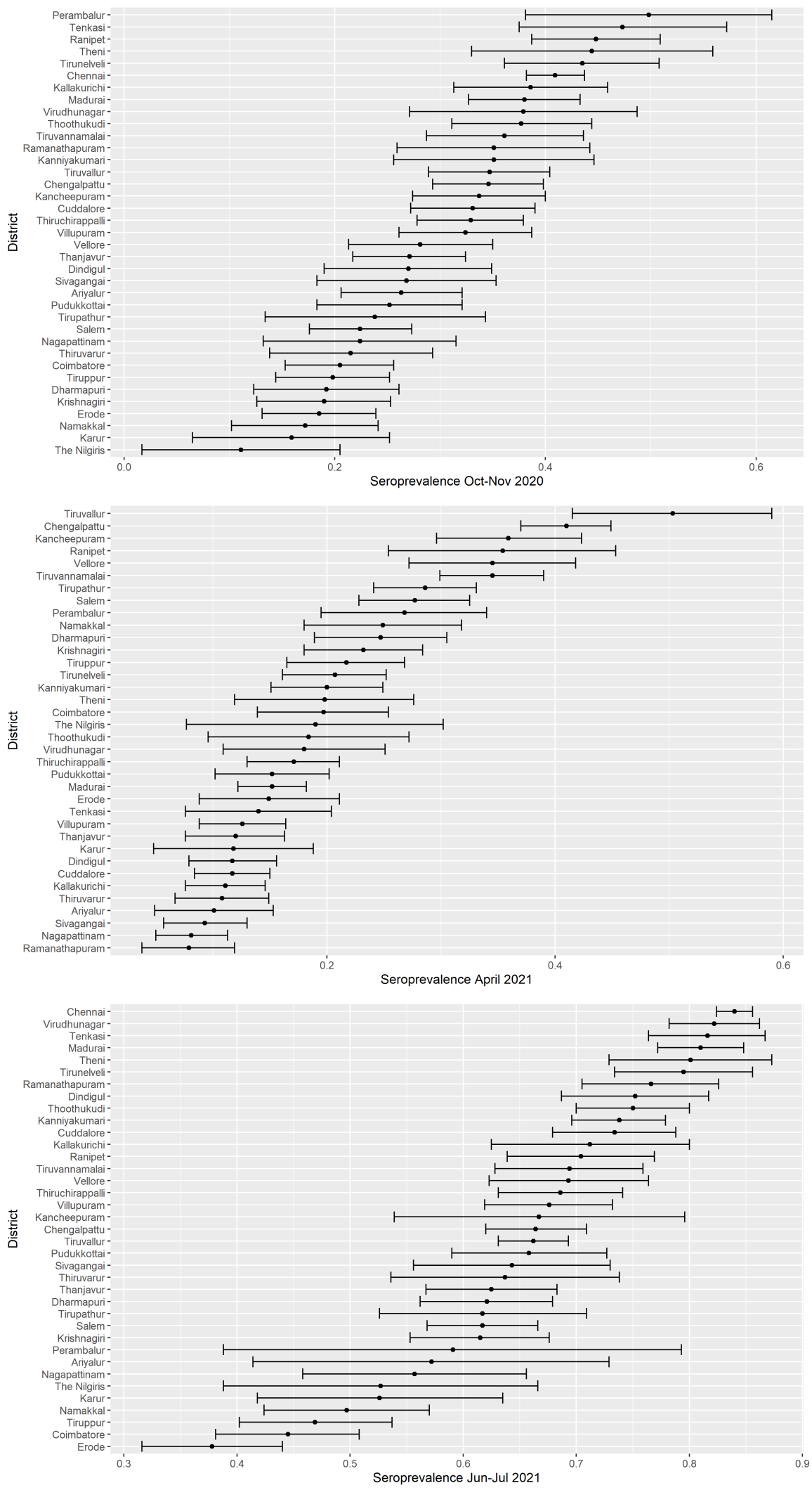
medRxiv preprint doi: https://doi.org/10.1101/2021.11.14.21265758; this version posted November 15, 2021. The copyright holder for this preprint (which was not certified by peer review) is the author/funder, who has granted medRxiv a license to display the preprint in perpetuity.

It is made available under a CC-BY 4.0 International license .

Figure 3. Relationship between rate of undercounting and testing rate in Round 1.

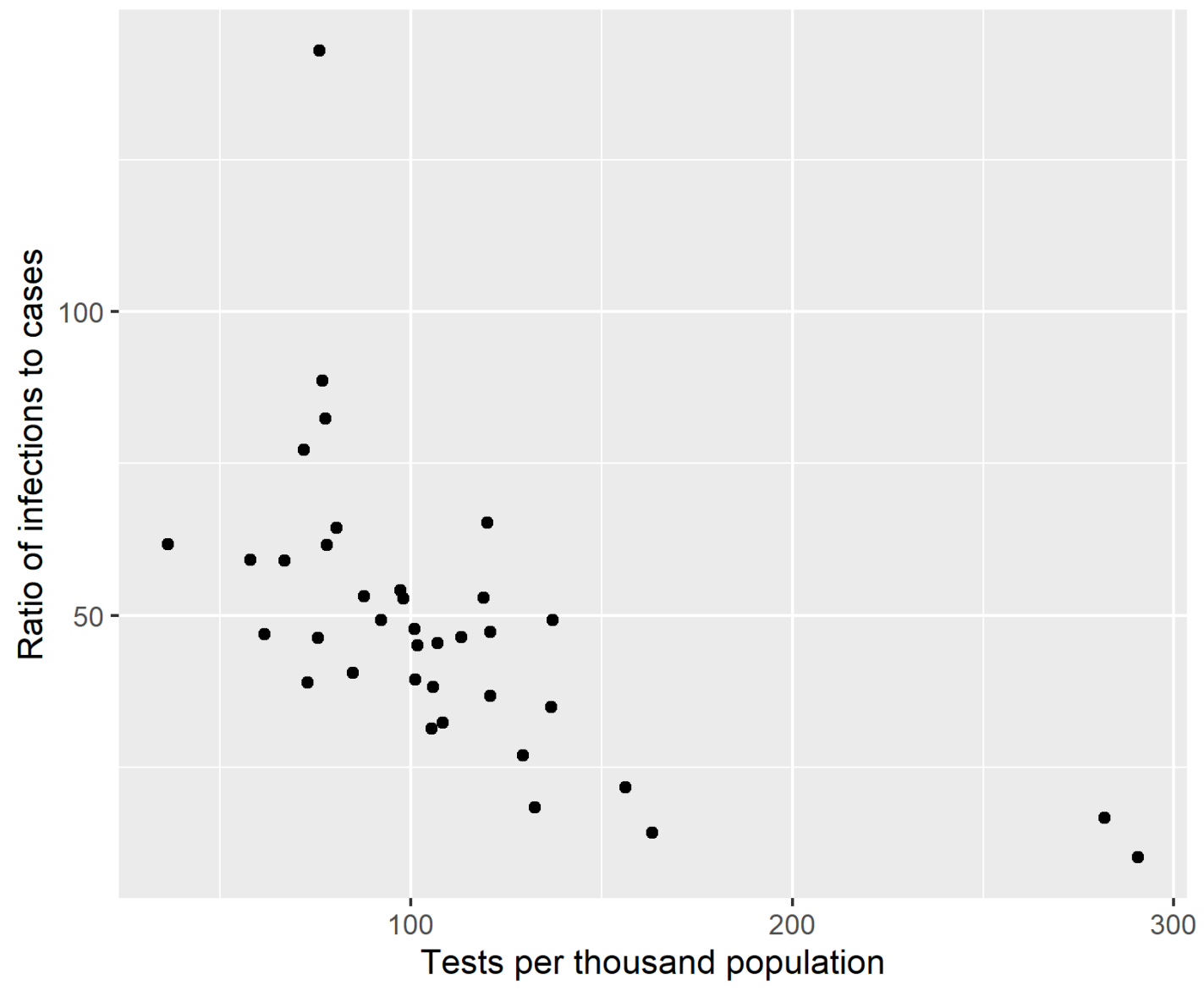

Notes. Each point represents a district. The x-axis presents the number of tests in a district divided by the 2011 Census population in that district. The y-axis presents the ratio of actual cases to confirmed cases. Actual cases are the estimated seroprevalence (\%) in the district times its 2011 Census population. The confirmed cases are counts up to 7 days before the median date of serological sampling in the district. 
medRxiv preprint doi: https://doi.org/10.1101/2021.11.14.21265758; this version posted November 15, 2021. The copyright holder for this preprint (which was not certified by peer review) is the author/funder, who has granted medRxiv a license to display the preprint in perpetuity.

It is made available under a CC-BY 4.0 International license .

Figure 4 Serological test values against district seroprevalence

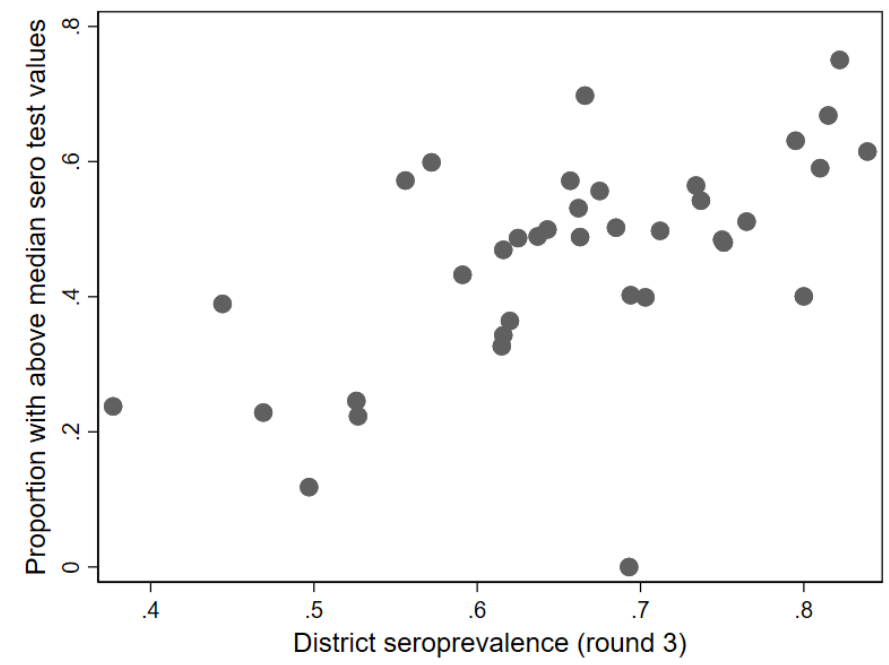

Notes: To plot this figure, for each type of test we calculate the median serological values in the entire state among the vaccinated and seropositive individuals surveyed in round 3 . We then compute the proportion of individuals in each district with serological values above mean weighted by sampling weights. This proportion is plotted against the overall seroprevalence in the district. 
medRxiv preprint doi: https://doi.org/10.1101/2021.11.14.21265758; this version posted November 15, 2021. The copyright holder for this preprint (which was not certified by peer review) is the author/funder, who has granted medRxiv a license to display the preprint in perpetuity.

It is made available under a CC-BY 4.0 International license .

Figure 5. Serological values in rounds 1 and 3.
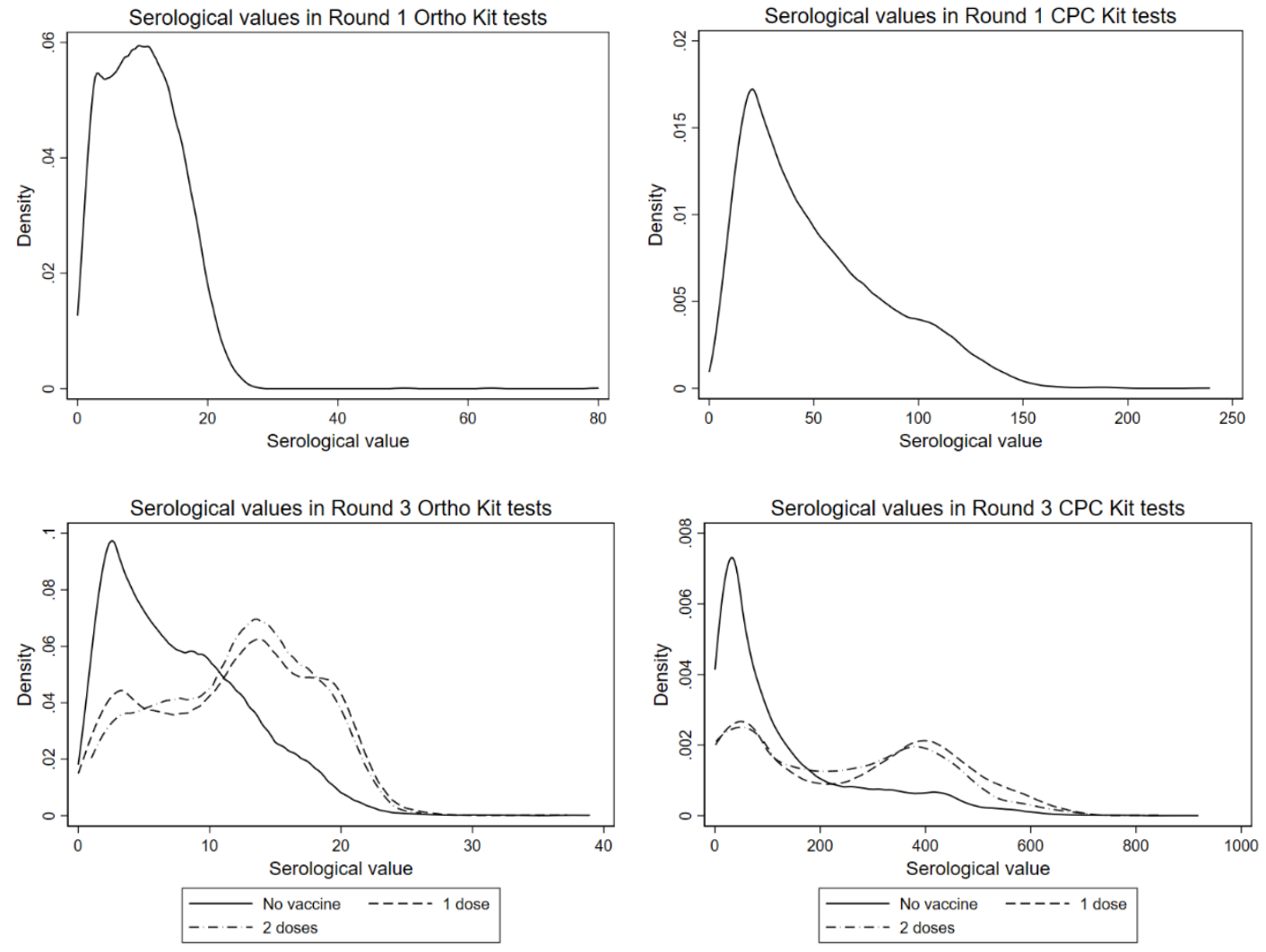
medRxiv preprint doi: https://doi.org/10.1101/2021.11.14.21265758; this version posted November 15, 2021. The copyright holder for this preprint (which was not certified by peer review) is the author/funder, who has granted medRxiv a license to display the preprint in perpetuity.

It is made available under a CC-BY 4.0 International license .

Table 1. Demographics of sample, as compared to 2011 Census.

\begin{tabular}{|c|c|c|c|c|c|}
\hline & & \multicolumn{3}{|l|}{ Sample } & \multirow[b]{2}{*}{$\begin{array}{c}\text { Census } \\
2011\end{array}$} \\
\hline & & $\begin{array}{l}\text { Oct- } \\
\text { Nov } \\
2020\end{array}$ & $\begin{array}{c}\text { Apr } \\
2021\end{array}$ & $\begin{array}{c}\text { Jun-Jul } \\
2021\end{array}$ & \\
\hline \multirow[t]{2}{*}{ Gender } & Male & $39 \%$ & $42 \%$ & $42 \%$ & $50 \%$ \\
\hline & Female & $61 \%$ & $58 \%$ & $58 \%$ & $50 \%$ \\
\hline \multirow[t]{6}{*}{ Age } & $18-29$ & $23 \%$ & $17 \%$ & $19 \%$ & $27 \%$ \\
\hline & $30-39$ & $23 \%$ & $21 \%$ & $23 \%$ & $24 \%$ \\
\hline & $40-49$ & $20 \%$ & $21 \%$ & $22 \%$ & $20 \%$ \\
\hline & $50-59$ & $16 \%$ & $18 \%$ & $18 \%$ & $14 \%$ \\
\hline & $60-69$ & $11 \%$ & $14 \%$ & $12 \%$ & $10 \%$ \\
\hline & $70+$ & $6 \%$ & $8 \%$ & $6 \%$ & $6 \%$ \\
\hline Obs. & & 26,135 & 21,931 & 26,592 & \\
\hline
\end{tabular}

Note. Census 2011 number for ages 18-29 includes only those ages 20-29.

Table 2. Seroprevalence by type of region, sex, and age.

\begin{tabular}{|c|c|c|c|c|c|c|c|c|c|c|}
\hline \multirow[b]{2}{*}{ Variable } & & \multicolumn{3}{|c|}{ (1) Oct-Nov 2020} & \multicolumn{3}{|c|}{ (2) April 2021} & \multicolumn{3}{|c|}{ (3) June-July 2021} \\
\hline & & $\begin{array}{c}\text { Seropre- } \\
\text { valence }\end{array}$ & $\begin{array}{c}\mathrm{Cl} \\
\text { lower } \\
\text { bound }\end{array}$ & $\begin{array}{c}\mathrm{Cl} \\
\text { upper } \\
\text { bound }\end{array}$ & $\begin{array}{c}\text { Seropre- } \\
\text { valence }\end{array}$ & $\begin{array}{c}\mathrm{Cl} \\
\text { lower } \\
\text { bound }\end{array}$ & $\begin{array}{c}\mathrm{Cl} \\
\text { upper } \\
\text { bound }\end{array}$ & $\begin{array}{l}\text { Seropre- } \\
\text { valence }\end{array}$ & $\begin{array}{c}\mathrm{Cl} \\
\text { lower } \\
\text { bound }\end{array}$ & $\begin{array}{c}\mathrm{Cl} \\
\text { upper } \\
\text { bound }\end{array}$ \\
\hline \multirow[t]{2}{*}{ Region } & Rural & $25.7 \%$ & $24.3 \%$ & $27.0 \%$ & & & & $64.1 \%$ & $62.9 \%$ & $65.4 \%$ \\
\hline & Urban & $35.7 \%$ & $34.0 \%$ & $37.4 \%$ & & & & $74.8 \%$ & $73.1 \%$ & $76.6 \%$ \\
\hline \multirow[t]{2}{*}{ Sex } & Male & $30.2 \%$ & $28.8 \%$ & $31.7 \%$ & $21.3 \%$ & $20.0 \%$ & $22.6 \%$ & $65.5 \%$ & $64.2 \%$ & $66.7 \%$ \\
\hline & Female & $30.8 \%$ & $29.5 \%$ & $32.0 \%$ & $22.0 \%$ & $20.8 \%$ & $23.1 \%$ & $67.5 \%$ & $66.2 \%$ & $68.7 \%$ \\
\hline \multirow[t]{6}{*}{ Age } & $18-29$ & $30.4 \%$ & $28.7 \%$ & $32.2 \%$ & $19.5 \%$ & $17.8 \%$ & $21.1 \%$ & $67.7 \%$ & $66.1 \%$ & $69.3 \%$ \\
\hline & $30-39$ & $30.7 \%$ & $29.0 \%$ & $32.5 \%$ & $21.2 \%$ & $19.6 \%$ & $22.8 \%$ & $67.0 \%$ & $65.4 \%$ & $68.6 \%$ \\
\hline & $40-49$ & $31.7 \%$ & $30.0 \%$ & $33.5 \%$ & $22.1 \%$ & $20.4 \%$ & $23.9 \%$ & $66.7 \%$ & $65.0 \%$ & $68.4 \%$ \\
\hline & $50-59$ & $32.2 \%$ & $30.3 \%$ & $34.1 \%$ & $25.6 \%$ & $23.8 \%$ & $27.4 \%$ & $66.6 \%$ & $64.8 \%$ & $68.5 \%$ \\
\hline & $60-69$ & $28.4 \%$ & $26.2 \%$ & $30.5 \%$ & $22.8 \%$ & $21.0 \%$ & $24.6 \%$ & $65.0 \%$ & $62.8 \%$ & $67.2 \%$ \\
\hline & $70+$ & $26.5 \%$ & $23.7 \%$ & $29.2 \%$ & $21.5 \%$ & $19.0 \%$ & $23.9 \%$ & $59.6 \%$ & $56.8 \%$ & $62.3 \%$ \\
\hline \multirow{2}{*}{$\begin{array}{l}\text { Vacci- } \\
\text { nated? }\end{array}$} & Yes & & & & $25.7 \%$ & $23.3 \%$ & $28.1 \%$ & $80.0 \%$ & $78.2 \%$ & $81.7 \%$ \\
\hline & No & $30.5 \%$ & $29.4 \%$ & $31.6 \%$ & $20.9 \%$ & $19.9 \%$ & $22.0 \%$ & $62.3 \%$ & $61.2 \%$ & $63.3 \%$ \\
\hline
\end{tabular}

Note. Data on urban status of clusters is not available from Round 2. Vaccinations were not available during round 1. 
medRxiv preprint doi: https://doi.org/10.1101/2021.11.14.21265758; this version posted November 15, 2021. The copyright holder for this preprint (which was not certified by peer review) is the author/funder, who has granted medRxiv a license to display the preprint in perpetuity.

It is made available under a CC-BY 4.0 International license .

Table 3. Confirmed cases and undercount of infections by district.

\begin{tabular}{|c|c|c|c|c|c|c|c|c|c|}
\hline \multirow[b]{3}{*}{ District } & \multicolumn{3}{|c|}{ Round 1 (Oct-Nov 2020) } & \multicolumn{3}{|c|}{ Round 2 (Apr 2021) } & \multicolumn{3}{|c|}{ Round 3 (June-July 2021) } \\
\hline & & $\begin{array}{l}\text { Total } \\
\text { cases }\end{array}$ & & & $\begin{array}{l}\text { Total } \\
\text { cases }\end{array}$ & & & $\begin{array}{l}\text { Total } \\
\text { cases }\end{array}$ & \\
\hline & $\begin{array}{c}\text { Seropre- } \\
\text { valence }\end{array}$ & $\begin{array}{c}\text { till } \\
\text { survey }\end{array}$ & $\begin{array}{l}\text { Under- } \\
\text { count }\end{array}$ & $\begin{array}{l}\text { Seropre- } \\
\text { valence }\end{array}$ & $\begin{array}{c}\text { till } \\
\text { survey }\end{array}$ & $\begin{array}{l}\text { Under- } \\
\text { count }\end{array}$ & $\begin{array}{c}\text { Seropre- } \\
\text { valence }\end{array}$ & $\begin{array}{c}\text { till } \\
\text { survey }\end{array}$ & $\begin{array}{l}\text { Under- } \\
\text { count }\end{array}$ \\
\hline Ariyalur & $26.3 \%$ & 4191 & 50 & $10.1 \%$ & 4855 & 17 & $57.2 \%$ & 14555 & 31 \\
\hline Chengalpattu & $34.5 \%$ & 40241 & 23 & $40.9 \%$ & 58226 & 19 & $66.3 \%$ & 155696 & 12 \\
\hline Chennai & $40.9 \%$ & 207390 & 10 & & & & $83.9 \%$ & 531127 & 8 \\
\hline Coimbatore & $20.4 \%$ & 37932 & 20 & $19.6 \%$ & 60821 & 12 & $44.4 \%$ & 216506 & 8 \\
\hline Cuddalore & $33.1 \%$ & 22170 & 41 & $11.6 \%$ & 26077 & 12 & $73.4 \%$ & 57371 & 35 \\
\hline Dharmapuri & $19.2 \%$ & 4954 & 62 & $24.6 \%$ & 6864 & 57 & $62.0 \%$ & 23956 & 41 \\
\hline Dindigul & $27.0 \%$ & 9465 & 65 & $11.6 \%$ & 12126 & 22 & $75.1 \%$ & 31380 & 55 \\
\hline Erode & $18.5 \%$ & 8644 & 51 & $14.9 \%$ & 15575 & 23 & $37.7 \%$ & 87110 & 10 \\
\hline Kallakurichi & $38.6 \%$ & 9802 & 57 & $11.1 \%$ & 11026 & 15 & $71.2 \%$ & 26474 & 39 \\
\hline Kancheepuram & $33.7 \%$ & 23941 & 17 & $35.8 \%$ & 31234 & 14 & $66.6 \%$ & 69799 & 12 \\
\hline Kanniyakumari & $35.1 \%$ & 14158 & 49 & $20.0 \%$ & 17758 & 22 & $73.7 \%$ & 58527 & 25 \\
\hline Karur & $15.8 \%$ & 3664 & 49 & $11.8 \%$ & 5735 & 23 & $52.6 \%$ & 21820 & 27 \\
\hline Krishnagiri & $18.9 \%$ & 5857 & 64 & $23.1 \%$ & 8720 & 53 & $61.5 \%$ & 39320 & 31 \\
\hline Madurai & $37.9 \%$ & 18014 & 68 & $15.1 \%$ & 22290 & 22 & $81.0 \%$ & 71894 & 36 \\
\hline Nagapattinam & $22.4 \%$ & 5959 & 64 & $8.1 \%$ & 9562 & 15 & $55.6 \%$ & 37651 & 25 \\
\hline Namakkal & $17.2 \%$ & 7845 & 40 & $24.8 \%$ & 12286 & 37 & $49.7 \%$ & 43739 & 21 \\
\hline Perambalur & $49.7 \%$ & 2010 & 148 & $26.8 \%$ & 2323 & 69 & $59.1 \%$ & 10942 & 32 \\
\hline Pudukkottai & $25.2 \%$ & 10001 & 43 & $15.1 \%$ & 12005 & 22 & $65.7 \%$ & 26604 & 42 \\
\hline Ramanathapuram & $35.1 \%$ & 5778 & 87 & $7.9 \%$ & 6634 & 17 & $76.5 \%$ & 19514 & 56 \\
\hline Ranipet & $44.8 \%$ & 14326 & 40 & $35.4 \%$ & 16623 & 27 & $70.3 \%$ & 40533 & 22 \\
\hline Salem & $22.4 \%$ & 25144 & 33 & $27.7 \%$ & 33864 & 30 & $61.6 \%$ & 86120 & 26 \\
\hline Sivagangai & $26.8 \%$ & 5580 & 68 & $9.3 \%$ & 7126 & 19 & $64.3 \%$ & 17350 & 53 \\
\hline Tenkasi & $47.2 \%$ & 7702 & 91 & $14.0 \%$ & 8843 & 24 & $81.5 \%$ & 26388 & 46 \\
\hline Thanjavur & $27.0 \%$ & 14486 & 47 & $11.9 \%$ & 20494 & 15 & $62.5 \%$ & 62443 & 26 \\
\hline The Nilgiris & $11.1 \%$ & 5510 & 16 & $18.9 \%$ & 8791 & 17 & $52.7 \%$ & 27858 & 15 \\
\hline Theni & $44.4 \%$ & 15888 & 37 & $19.7 \%$ & 17397 & 15 & $80.0 \%$ & 42060 & 25 \\
\hline Thiruchirappalli & $32.8 \%$ & 11645 & 81 & $17.1 \%$ & 16347 & 30 & $68.5 \%$ & 68302 & 29 \\
\hline Thiruvarur & $21.5 \%$ & 8620 & 33 & $10.8 \%$ & 12419 & 12 & $63.7 \%$ & 36506 & 23 \\
\hline Thoothukudi & $37.7 \%$ & 14391 & 49 & $18.4 \%$ & 16678 & 20 & $75.0 \%$ & 53999 & 26 \\
\hline Tirunelveli & $43.5 \%$ & 13684 & 56 & $20.7 \%$ & 16436 & 22 & $79.5 \%$ & 47137 & 30 \\
\hline Tirupathur & $23.8 \%$ & 5843 & 48 & $28.6 \%$ & 7914 & 43 & $61.6 \%$ & 27392 & 26 \\
\hline Tiruppur & $19.7 \%$ & 10209 & 51 & $21.6 \%$ & 19860 & 29 & $46.9 \%$ & 80789 & 15 \\
\hline Tiruvallur & $34.7 \%$ & 35320 & 39 & $50.3 \%$ & 47087 & 42 & $66.2 \%$ & 110374 & 24 \\
\hline Tiruvannamalai & $36.1 \%$ & 16804 & 56 & $34.4 \%$ & 19883 & 45 & $69.4 \%$ & 48576 & 37 \\
\hline Vellore & $28.0 \%$ & 16854 & 28 & $34.4 \%$ & 21772 & 27 & $69.3 \%$ & 46663 & 25 \\
\hline Villupuram & $32.4 \%$ & 12712 & 56 & $12.6 \%$ & 15668 & 18 & $67.5 \%$ & 42133 & 36 \\
\hline Virudhunagar & $37.9 \%$ & 14980 & 52 & $18.0 \%$ & 16980 & 22 & $82.2 \%$ & 44216 & 38 \\
\hline
\end{tabular}

Note. Chennai district was not included in sampling during round 2 . 
medRxiv preprint doi: https://doi.org/10.1101/2021.11.14.21265758; this version posted November 15, 2021. The copyright holder for this preprint (which was not certified by peer review) is the author/funder, who has granted medRxiv a license to display the preprint in perpetuity.

It is made available under a CC-BY 4.0 International license .

Table 4. Decay of antibodies form natural infection.

(1) (2)

Seroprevalence: Round 2

Seroprevalence: $\quad 0.684^{* * *} \quad 0.374 * *$

Round $1 \quad$ (0.0635) (0.114)

Adjusted case count $\quad 1.111^{* *}$

$(0.354)$

\begin{tabular}{l}
$\mathrm{N} 36$ \\
\hline Notes. This table presents the results from regressing \\
seroprevalence at the district level in round 2 against \\
seroprevalence at the district level in round 1 and no \\
constant. In column 2, the regression also includes the \\
district-level adjusted case count to capture the risk of \\
COVID infection.
\end{tabular}

Table 5. Decay in serological values over days since vaccine dose.

\begin{tabular}{lllll}
\hline & $(1)$ & $(2)$ & \multicolumn{3}{c}{$(3)$} & $(4)$ \\
& \multicolumn{5}{c}{ Serological values } \\
\cline { 2 - 5 } Days since dose 1 & 0.0183 & -0.0649 & -0.316 & -0.00643 \\
& $(0.219)$ & $(0.0629)$ & $(0.757)$ & $(0.271)$ \\
& & & & \\
Constant & $208.5^{* * *}$ & $19.22^{* * *}$ & $226.8^{* * *}$ & 15.76 \\
& $(13.30)$ & $(4.084)$ & $(41.87)$ & $(16.06)$ \\
\hline \multirow{2}{*}{$\mathrm{N}$} & & & & \\
Kit & 1184 & 929 & 1184 & 929 \\
Instruments & CPC Kit & Ortho Kit & CPC Kit & Ortho Kit \\
\hline
\end{tabular}

Notes. This table presents the results from regressing serological values against days since first dose among respondents in round 3 who have received exactly 1 vaccine dose. In columns 3 and 4 , days since dose 1 is instrumented with age. 


\title{
SUPPLEMENT \\ Seroprevalence in Tamil Nadu in October-November 2020
}

\author{
Selvavinayagam T.S., Somasundaram A., Jerard Maria Selvam, \\ Sabareesh Ramachandran, Sampath P., Vijayalakshmi V., Ajith Brabhu Kumar C., \\ Sudharshini Subramaniam, Raju. S, Avudaiselvi. R, Prakash V., Yogananth N., \\ Gurunathan Subramanian, Roshini. A, Dhiliban D.N., Sofia Imad, Vaidehi Tandel, \\ Rajeswari Parasa, Stuti Sachdeva, Anup Malani*
}

\section{Methods}

Sampling. Numerous clusters had less or more than 30 persons sampled. We report those in Table S 1. We retain all samples because it is unclear which samples to drop from clusters with $>30$ observations.

Table S 1. Number of samples per cluster.

\begin{tabular}{|c|c|c|c|}
\hline \multirow{2}{*}{$\begin{array}{l}\text { Samples } \\
\text { per cluster }\end{array}$} & \multicolumn{3}{|c|}{ Number of clusters } \\
\hline & Oct-Nov 2020 & Apr 2021 & Jun-Jul 2021 \\
\hline 1 & & 2 & \\
\hline 4 & 1 & & \\
\hline 5 & & 1 & \\
\hline 6 & 1 & & \\
\hline 8 & 1 & & \\
\hline 9 & 1 & 1 & \\
\hline 10 & 1 & & \\
\hline 15 & 1 & & \\
\hline 17 & & 1 & \\
\hline 19 & 3 & & \\
\hline 20 & 3 & 2 & \\
\hline 21 & 1 & 2 & \\
\hline 22 & & 3 & \\
\hline 23 & 1 & 3 & \\
\hline 24 & 2 & 1 & \\
\hline 25 & 3 & 4 & \\
\hline 26 & 2 & 5 & 2 \\
\hline
\end{tabular}

\footnotetext{
${ }^{*}$ Directorate of Public Health \& Preventative Medicine, Government of Tamil Nadu: Selvavinayagam, T.S., Somasundaram A., Jerard Maria Selvam, Sampath P., Vijayalakshmi V., Ajith Brabhu Kumar C., Sudharshini Subramaniam, S. Raju, Avudaiselvi, Prakash V., Yogananth N., Roshini, and Dhilipan; University of California, San Diego: Sabareesh Ramachandran; IDFC Institute: Sofia Imad. Rajeshwari Parasa; independent: Vaidehi Tandel and Stuti Sachdeva; University of Chicago: Anup Malani. Corresponding author (amalani@uchicago.edu).
} 


\begin{tabular}{cccc}
27 & 8 & 9 & 5 \\
28 & 19 & 26 & 7 \\
\hline 29 & 44 & 124 & 11 \\
\hline 30 & 774 & 562 & 863 \\
\hline 31 & 13 & & \\
32 & 2 & & \\
\hline 36 & 1 & & \\
\hline \hline
\end{tabular}

Sample size. Sampling 300 per million would lead to different sample sizes per district. Because some clusters yielded less than 30 persons per cluster, the sample per million population may vary from the $\mathbf{3 0 0}$ per million target. The following table presents the sample size obtained and the resulting minimum detectable effect in each district. These are reported in Table S 2. Assuming a design effect of 2, the implied minimum detectable effect (MDE) per district varies in Round 1, e.g., from 3.3 (Chennai) to 13.6 (Nagapattinam) percentage points.

Table S 2. Sample size obtained per district and implied minimum detectable effect.

\begin{tabular}{lccccccc}
\hline \multirow{2}{*}{ District } & \multicolumn{2}{c}{ Oct-Nov 2020 } & \multicolumn{2}{c}{ Apr 2021 } & \multicolumn{2}{c}{ Jun-Jul 2021 } \\
\cline { 2 - 7 } & $\begin{array}{c}\text { Sample } \\
\text { size }\end{array}$ & MDE & $\begin{array}{c}\text { Sample } \\
\text { size }\end{array}$ & MDE & $\begin{array}{c}\text { Sample } \\
\text { size }\end{array}$ & MDE \\
\hline \hline Ariyalur & 270 & 0.119 & 268 & 0.119 & 270 & 0.119 \\
\hline Chengalpattu & 720 & 0.072 & 688 & 0.075 & 960 & 0.063 \\
\hline Chennai & 3613 & 0.032 & 0 & & 3672 & 0.032 \\
\hline Coimbatore & 1182 & 0.057 & 1225 & 0.056 & 1246 & 0.056 \\
\hline Cuddalore & 870 & 0.065 & 863 & 0.067 & 870 & 0.065 \\
\hline Dharmapuri & 567 & 0.082 & 556 & 0.082 & 570 & 0.082 \\
\hline Dindigul & 717 & 0.072 & 711 & 0.074 & 720 & 0.072 \\
\hline Erode & 745 & 0.071 & 746 & 0.071 & 780 & 0.070 \\
\hline Kallakurichi & 596 & 0.079 & 595 & 0.079 & 420 & 0.096 \\
\hline Kancheepuram & 480 & 0.089 & 470 & 0.090 & 240 & 0.127 \\
\hline Kanniyakumari & 659 & 0.075 & 656 & 0.076 & 660 & 0.075 \\
\hline Karur & 390 & 0.098 & 389 & 0.098 & 390 & 0.098 \\
\hline Krishnagiri & 690 & 0.075 & 655 & 0.076 & 660 & 0.075 \\
\hline Madurai & 1140 & 0.057 & 1116 & 0.059 & 1140 & 0.057 \\
\hline Nagapattinam & 529 & 0.085 & 528 & 0.085 & 570 & 0.082 \\
\hline Namakkal & 600 & 0.079 & 561 & 0.082 & 597 & 0.079 \\
\hline Perambalur & 209 & 0.136 & 207 & 0.136 & 210 & 0.135 \\
\hline Pudukkottai & 599 & 0.079 & 586 & 0.081 & 600 & 0.079 \\
\hline Ramanathapuram & 480 & 0.089 & 478 & 0.090 & 480 & 0.089 \\
\hline Ranipet & 420 & 0.096 & 282 & 0.116 & 420 & 0.096 \\
\hline Salem & 1260 & 0.054 & 1255 & 0.054 & 1260 & 0.054 \\
\hline
\end{tabular}


medRxiv preprint doi: https://doi.org/10.1101/2021.11.14.21265758; this version posted November 15, 2021. The copyright holder for this preprint (which was not certified by peer review) is the author/funder, who has granted medRxiv a license to display the preprint in perpetuity.

It is made available under a CC-BY 4.0 International license .

\begin{tabular}{lllllll} 
Sivagangai & 450 & 0.092 & 450 & 0.092 & 450 & 0.092 \\
\hline Tenkasi & 420 & 0.096 & 414 & 0.096 & 540 & 0.083 \\
\hline Thanjavur & 834 & 0.068 & 828 & 0.068 & 840 & 0.068 \\
\hline The Nilgiris & 223 & 0.130 & 235 & 0.128 & 237 & 0.127 \\
\hline Theni & 420 & 0.096 & 418 & 0.096 & 420 & 0.096 \\
\hline Thiruchirappalli & 957 & 0.063 & 896 & 0.064 & 960 & 0.063 \\
\hline Thiruvarur & 420 & 0.096 & 417 & 0.096 & 420 & 0.096 \\
\hline Thoothukudi & 547 & 0.083 & 464 & 0.090 & 570 & 0.082 \\
\hline Tirunelveli & 630 & 0.078 & 625 & 0.078 & 510 & 0.086 \\
\hline Tirupathur & 329 & 0.108 & 326 & 0.108 & 300 & 0.112 \\
\hline Tiruppur & 740 & 0.071 & 796 & 0.068 & 801 & 0.068 \\
\hline Tiruvallur & 745 & 0.071 & 799 & 0.068 & 839 & 0.068 \\
\hline Tiruvannamalai & 810 & 0.068 & 809 & 0.068 & 840 & 0.068 \\
\hline Vellore & 592 & 0.081 & 530 & 0.085 & 660 & 0.075 \\
\hline Villupuram & 594 & 0.079 & 583 & 0.081 & 780 & 0.070 \\
\hline Virudhunagar & 688 & 0.075 & 506 & 0.086 & 690 & 0.075 \\
\hline \hline
\end{tabular}

Sample. Suspected or confirmed current or prior COVID-19 infection was not an exclusion criterion. If a participant was currently receiving medical care for COVID-19, a family member or proxy was used to complete the questionnaire on the participant's behalf; however, the blood sample was taken from the participant.

Data collection. Blood was collected in EDTA vacutainers. Serum was isolated and stored in Eppendorf tubes. Serum was analyzed using either of two chemiluminescent immunoassay (CLIA) kits.

The first kit was the iFlash-SARS-CoV-2 IgG kit from Shenzhen YHLO Biotech. Per the manufacturer, it has a sensitivity of $95.9 \%(95 \% \mathrm{Cl}: 93.3-97.5 \%)$ and specificity of $95.7 \%(95 \% \mathrm{Cl}$ : 92.5-97.6\%) ${ }^{4}$. Independent analysis estimated a sensitivity of 93\% (95\% Cl: 84.3-97.7\%) and specificity of $92.9 \%(95 \% \mathrm{Cl}: 85.3-97.4 \%)^{9}$.

The second kit was the Vitros anti-SARS-CoV-2 IgG CLIA from Ortho-Clinical Diagnostics. Per the manufacturer it has $90 \%$ sensitivity (95\% Cl: 76.3-97.2\%) and $100 \%$ specificity (95\% Cl: $99.1-$ $100.0 \%)^{5}$. FDA evaluation suggests it has $100 \%$ sensitivity $(95 \% \mathrm{Cl}: 88.7-100 \%)$ and $100 \%$ specificity (95\% Cl: $95.4-100 \%)^{10}$. Independent analysis estimated that it has a sensitivity of 98.8\% (95\% Cl: $92.9-100 \%)$ and specificity of $97.3 \%(95 \% \mathrm{Cl}: 85-100 \%)^{11}$. 
medRxiv preprint doi: https://doi.org/10.1101/2021.11.14.21265758; this version posted November 15, 2021. The copyright holder for this preprint (which was not certified by peer review) is the author/funder, who has granted medRxiv a license to display the preprint in perpetuity.

It is made available under a CC-BY 4.0 International license .

All the samples in a district are analyzed using the same kit, with the exception of the Chennai. In Chennai 2 HUDs used 1 kit, one used the other. Table S 3 reports the test kit used in each district.

Table S 3. Test kit used in each district.

\begin{tabular}{|c|c|c|c|}
\hline District & Type of Kit & District & Type of Kit \\
\hline Ariyalur & CPC Kit & Ramanathapuram & CPC Kit \\
\hline Chengalpattu & Ortho Kit & Ranipet & Ortho Kit \\
\hline Chennai & CPC \& Ortho kits* & Salem & Ortho Kit \\
\hline Coimbatore & Ortho Kit & Sivagangai & CPC Kit \\
\hline Cuddalore & CPC Kit & Tenkasi & CPC Kit \\
\hline Dharmapuri & Ortho Kit & Thanjavur & CPC Kit \\
\hline Dindigul & CPC Kit & The Nilgiris & Ortho Kit \\
\hline Erode & Ortho Kit & Theni & CPC Kit \\
\hline Kallakurichi & CPC Kit & Thiruchirappalli & CPC Kit \\
\hline Kancheepuram & Ortho Kit & Thiruvarur & CPC Kit \\
\hline Kanniyakumari & CPC Kit & Thoothukudi & CPC Kit \\
\hline Karur & CPC Kit & Tirunelveli & CPC Kit \\
\hline Krishnagiri & Ortho Kit & Tirupathur & Ortho Kit \\
\hline Madurai & CPC Kit & Tiruppur & Ortho Kit \\
\hline Mayiladuthurai & CPC Kit & Tiruvallur & Ortho Kit \\
\hline Nagapattinam & CPC Kit & Tiruvannamalai & Ortho Kit \\
\hline Namakkal & Ortho Kit & Vellore & CPC \& Ortho Kits* \\
\hline Perambalur & CPC Kit & Villupuram & CPC Kit \\
\hline Pudukkottai & CPC Kit & Virudhunagar & CPC \& Ortho Kits* \\
\hline
\end{tabular}

\section{Statistical analysis.}

Nagapattinam district was split into Nagapattinam and Mayiladuthurai districts in March 2020, after the state started reported data on confirmed cases but before we conducted our serological survey. We aggregate these two districts together in our estimates of seropositivity and seroprevalence.

In Chennai, we do not have the population by HUDs. Since the samples were drawn proportional to population, we divide the district population across the HUDs in proportion to the sample size. 
When estimating our district-level seroprevalence, the weights for our regression analysis employ data from the 2011 Census for the population in each age $x$ gender category in each district. We estimate the sampling probability for demographic group (age category $x$ sex) as the number of observations in that group in the sample in a district divided by the census population in that group in a district.

When estimating our urban- and rural-level seroprevalence, the weights for our regression analysis employ data from the 2011 Census for the population in each urban/rural category in each district. We estimate the sampling probability for urban/rural group as the number of observations in that group in the sample in a district divided by the census population in that group in a district.

We calculate the sampling probabilities for each regression observation at the level of 2011defined districts (of which there are 32) rather than the 2020-defined districts (of which there are 38), HUDs or clusters because the population is available only at the level of the old 32 districts. Likewise, we calculate district weights when we aggregate estimates across districts using the 32, 2001 districts. The 38, 2020 districts are all the same or bifurcations of the 32, 2011 districts. Fortunately, in all bifurcated districts, the same kit was used. Therefore, we can combine all bifurcated districts into older 2011 districts for purposes of calculating sampling probabilities in regression analyses or weights when aggregating estimates.

\section{Results}

Table $\mathrm{S} 4$ provides the data behind Figure 2, which reports seroprevalence by district. Table $S 5$ reports seroprevalence by district and demographics. 
medRxiv preprint doi: https://doi.org/10.1101/2021.11.14.21265758; this version posted November 15, 2021. The copyright holder for this preprint (which was not certified by peer review) is the author/funder, who has granted medRxiv a license to display the preprint in perpetuity.

It is made available under a CC-BY 4.0 International license .

Table S 4. Seroprevalence by district.

\begin{tabular}{|c|c|c|c|}
\hline \multirow{2}{*}{ District } & \multicolumn{3}{|c|}{ Seroprevalence $(95 \% \mathrm{Cl})$} \\
\hline & Oct-Nov 2020 & Apr 2021 & Jun-Jul 2021 \\
\hline Ariyalur & $0.263(0.206,0.321)$ & $0.101(0.048,0.152)$ & $0.572(0.414,0.728)$ \\
\hline Chengalpattu & $0.345(0.293,0.398)$ & $0.409(0.370,0.449)$ & $0.663(0.620,0.708)$ \\
\hline Chennai & $0.409(0.381,0.437)$ & & $0.839(0.824,0.856)$ \\
\hline Coimbatore & $0.204(0.152,0.256)$ & $0.196(0.138,0.254)$ & $0.444(0.381,0.508)$ \\
\hline Cuddalore & $0.331(0.272,0.389)$ & $0.116(0.083,0.150)$ & $0.734(0.679,0.787)$ \\
\hline Dharmapuri & $0.192(0.123,0.261)$ & $0.246(0.188,0.305)$ & $0.620(0.561,0.679)$ \\
\hline Dindigul & $0.270(0.189,0.349)$ & $0.116(0.079,0.156)$ & $0.751(0.686,0.816)$ \\
\hline Erode & $0.185(0.130,0.238)$ & $0.149(0.087,0.210)$ & $0.377(0.316,0.439)$ \\
\hline Kallakurichi & $0.386(0.312,0.458)$ & $0.111(0.075,0.145)$ & $0.712(0.625,0.800)$ \\
\hline Kancheepuram & $0.337(0.273,0.400)$ & $0.358(0.296,0.423)$ & $0.666(0.538,0.796)$ \\
\hline Kanniyakumari & $0.351(0.256,0.446)$ & $0.200(0.150,0.248)$ & $0.737(0.695,0.778)$ \\
\hline Karur & $0.158(0.064,0.252)$ & $0.118(0.048,0.187)$ & $0.526(0.418,0.634)$ \\
\hline Krishnagiri & $0.189(0.126,0.252)$ & $0.231(0.180,0.284)$ & $0.615(0.552,0.675)$ \\
\hline Madurai & $0.379(0.326,0.432)$ & $0.151(0.122,0.181)$ & $0.810(0.772,0.847)$ \\
\hline Nagapattinam & $0.224(0.131,0.314)$ & $0.081(0.050,0.112)$ & $0.556(0.458,0.656)$ \\
\hline Namakkal & $0.172(0.101,0.240)$ & $0.248(0.180,0.317)$ & $0.497(0.423,0.569)$ \\
\hline Perambalur & $0.497(0.381,0.615)$ & $0.268(0.194,0.340)$ & $0.591(0.388,0.792)$ \\
\hline Pudukkottai & $0.252(0.182,0.321)$ & $0.151(0.101,0.202)$ & $0.657(0.589,0.726)$ \\
\hline Ramanathapuram & $0.351(0.259,0.442)$ & $0.079(0.037,0.119)$ & $0.765(0.704,0.825)$ \\
\hline Ranipet & $0.448(0.386,0.509)$ & $0.354(0.254,0.453)$ & $0.703(0.638,0.768)$ \\
\hline Salem & $0.224(0.175,0.273)$ & $0.277(0.228,0.324)$ & $0.616(0.568,0.666)$ \\
\hline Sivagangai & $0.268(0.182,0.352)$ & $0.093(0.057,0.129)$ & $0.643(0.555,0.730)$ \\
\hline Tenkasi & $0.472(0.375,0.572)$ & $0.140(0.075,0.203)$ & $0.815(0.763,0.866)$ \\
\hline Thanjavur & $0.270(0.216,0.324)$ & $0.119(0.075,0.163)$ & $0.625(0.566,0.683)$ \\
\hline The Nilgiris & $0.111(0.017,0.204)$ & $0.189(0.076,0.301)$ & $0.527(0.388,0.666)$ \\
\hline Theni & $0.444(0.330,0.559)$ & $0.197(0.119,0.275)$ & $0.800(0.728,0.873)$ \\
\hline Thiruchirappalli & $0.328(0.277,0.379)$ & $0.171(0.129,0.210)$ & $0.685(0.630,0.740)$ \\
\hline Thiruvarur & $0.215(0.137,0.293)$ & $0.108(0.067,0.149)$ & $0.637(0.536,0.737)$ \\
\hline Thoothukudi & $0.377(0.310,0.444)$ & $0.184(0.096,0.272)$ & $0.75(0.699,0.800)$ \\
\hline Tirunelveli & $0.435(0.361,0.508)$ & $0.207(0.160,0.252)$ & $0.795(0.734,0.856)$ \\
\hline Tirupathur & $0.238(0.134,0.342)$ & $0.286(0.240,0.331)$ & $0.616(0.526,0.708)$ \\
\hline Tiruppur & $0.197(0.143,0.252)$ & $0.216(0.165,0.268)$ & $0.469(0.402,0.537)$ \\
\hline Tiruvallur & $0.347(0.289,0.404)$ & $0.503(0.414,0.589)$ & $0.662(0.630,0.693)$ \\
\hline Tiruvannamalai & $0.361(0.287,0.435)$ & $0.344(0.298,0.389)$ & $0.694(0.628,0.759)$ \\
\hline Vellore & $0.280(0.212,0.349)$ & $0.344(0.272,0.418)$ & $0.693(0.623,0.763)$ \\
\hline Villupuram & $0.324(0.261,0.386)$ & $0.126(0.087,0.164)$ & $0.675(0.619,0.731)$ \\
\hline Virudhunagar & $0.379(0.270,0.486)$ & $0.180(0.108,0.250)$ & $0.822(0.782,0.861)$ \\
\hline
\end{tabular}

Note. Chennai district was not included in sampling during round 2 . 
medRxiv preprint doi: https://doi.org/10.1101/2021.11.14.21265758; this version posted November 15, 2021. The copyright holder for this preprint (which was not certified by peer review) is the author/funder, who has granted medRxiv a license to display the preprint in perpetuity.

It is made available under a CC-BY 4.0 International license .

Table S 5. Seroprevalence by district and demographic group in Round 1 (Oct-Nov 2020).

\begin{tabular}{|c|c|c|c|c|c|c|c|c|c|c|c|c|}
\hline \multirow{2}{*}{ istrict } & \multicolumn{6}{|c|}{ Male } & \multicolumn{6}{|c|}{ Female } \\
\hline & $18-29$ & $30-39$ & $40-49$ & $50-59$ & $60-69$ & $70+$ & $18-29$ & $30-39$ & $40-49$ & $50-59$ & $60-69$ & $70+$ \\
\hline Arivalur & $27.5 \%$ & $37.5 \%$ & $19.7 \%$ & $39.1 \%$ & $50 \%$ & $15.3 \%$ & $17.3 \%$ & $29.3 \%$ & $24.6 \%$ & $22.8 \%$ & $4.3 \%$ & $50 \%$ \\
\hline Chengalpattu & $44.4 \%$ & $25.6 \%$ & $39.8 \%$ & $39.3 \%$ & $31 \%$ & $10.8 \%$ & $34.9 \%$ & $31.7 \%$ & $40.7 \%$ & $36.3 \%$ & $32.6 \%$ & $18.2 \%$ \\
\hline Chennai & $38.8 \%$ & $35.6 \%$ & $40.2 \%$ & $47.2 \%$ & $33.1 \%$ & $30 \%$ & $44.2 \%$ & $41.8 \%$ & $49 \%$ & $44.1 \%$ & $30.7 \%$ & $42.3 \%$ \\
\hline Coimbatore & $21.2 \%$ & $15.5 \%$ & $21.8 \%$ & $24.1 \%$ & $14.5 \%$ & $11.4 \%$ & $15.9 \%$ & $25.9 \%$ & $21.8 \%$ & $25.4 \%$ & $21.6 \%$ & $21.1 \%$ \\
\hline Cuddalore & $34 \%$ & $29.6 \%$ & $21.6 \%$ & $34.4 \%$ & $24.4 \%$ & $5.9 \%$ & $27.7 \%$ & $43.5 \%$ & $40.2 \%$ & $51.3 \%$ & $40.7 \%$ & $25.7 \%$ \\
\hline Dharmapuri & $18.9 \%$ & $26.6 \%$ & $20.9 \%$ & $22.4 \%$ & $10.8 \%$ & $16 \%$ & $11.8 \%$ & $16.5 \%$ & $22.1 \%$ & $26.8 \%$ & $20.8 \%$ & $16 \%$ \\
\hline & & $28.9 \%$ & & & $27.3 \%$ & $21.1 \%$ & & $33.7 \%$ & $17.3 \%$ & $23.9 \%$ & $16.5 \%$ & $28.7 \%$ \\
\hline Erode & $33.3 \%$ & $26.6 \%$ & $11.8 \%$ & $13.6 \%$ & $17.2 \%$ & $3.7 \%$ & $17.9 \%$ & $13.8 \%$ & $17.9 \%$ & $13.7 \%$ & $15 \%$ & $18.4 \%$ \\
\hline Kallakurichi & $34.4 \%$ & $38.6 \%$ & $48.8 \%$ & $39.1 \%$ & $31.9 \%$ & $39.1 \%$ & $37.2 \%$ & $28.9 \%$ & $43.9 \%$ & $58.7 \%$ & $45.8 \%$ & $19.7 \%$ \\
\hline Kancheepur & $26.4 \%$ & $40.4 \%$ & $34.4 \%$ & $26.8 \%$ & $40.4 \%$ & $16 \%$ & $29.4 \%$ & $50.8 \%$ & $1 \%$ & $26.1 \%$ & $27.5 \%$ & $68 \%$ \\
\hline Kanniyakumari & $37.5 \%$ & 37 & $39.1 \%$ & $28.6 \%$ & $40.7 \%$ & $18 \%$ & $35.4 \%$ & $40 \%$ & & $28.7 \%$ & $24.5 \%$ & $19.7 \%$ \\
\hline Karur & $15.3 \%$ & $13.6 \%$ & $14.8 \%$ & $7.1 \%$ & $9.2 \%$ & $56.1 \%$ & $9.2 \%$ & $12 \%$ & $26.3 \%$ & $17.3 \%$ & $29.1 \%$ & $1.8 \%$ \\
\hline Kri & 1 & 17. & 17 & 17 & 10 & $50.8 \%$ & $20.9 \%$ & $20.2 \%$ & $18.5 \%$ & $19.7 \%$ & $37.7 \%$ & \\
\hline Mad & 38 & 25 & 36 & & & 5 & & $\%$ & $7 \%$ & $8 \%$ & $2 \%$ & \\
\hline Nagapatt & $27 \%$ & $24 \%$ & $28.9 \%$ & $38.6 \%$ & $22.8 \%$ & $12.8 \%$ & $14.2 \%$ & $16.8 \%$ & $23.2 \%$ & $22.8 \%$ & $14.4 \%$ & $\%$ \\
\hline Namakkal & & $18 \%$ & $18.7 \%$ & $16 \%$ & $24.7 \%$ & $7.4 \%$ & $18.8 \%$ & $19.3 \%$ & $13.6 \%$ & $17.3 \%$ & $7.8 \%$ & \\
\hline Perambalur & $42.3 \%$ & $54.2 \%$ & $64.9 \%$ & $43.9 \%$ & $20.7 \%$ & $39.1 \%$ & $52.3 \%$ & $50 \%$ & $63.8 \%$ & $60 \%$ & $0 \%$ & $\%$ \\
\hline $\mathrm{Pu}$ & 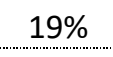 & $18.8 \%$ & $31 \%$ & 30 & 14 & $42.3 \%$ & $31 \%$ & $26.6 \%$ & $20.6 \%$ & $.4 \%$ & $.6 \%$ & $\%$ \\
\hline anathapuram & 2 & 38 & 1 & & & & $\%$ & $3 \%$ & $\%$ & $\%$ & $\%$ & \\
\hline Ranipet & $54.4 \%$ & $23.4 \%$ & $38.8 \%$ & $46.3 \%$ & $47.6 \%$ & $24.7 \%$ & $7 \%$ & $50.8 \%$ & $41.1 \%$ & $2 \%$ & $8 \%$ & $40.4 \%$ \\
\hline $\mathrm{Sa}$ & $\%$ & $23.7 \%$ & $29.8 \%$ & $31 \%$ & $23.8 \%$ & $12.9 \%$ & $4 \%$ & $4 \%$ & $4 \%$ & $5 \%$ & $6 \%$ & 12 \\
\hline & $28.2 \%$ & $22.8 \%$ & $34.7 \%$ & $20.2 \%$ & $37.7 \%$ & $14.4 \%$ & $26.6 \%$ & $26.6 \%$ & 32 & $8 \%$ & $2 \%$ & 16 \\
\hline Tenkasi & $50 \%$ & $44.6 \%$ & $43.9 \%$ & $46.2 \%$ & $64.9 \%$ & $31.9 \%$ & $46 \%$ & $47.7 \%$ & $5 \%$ & $2 \%$ & $6 \%$ & $40.9 \%$ \\
\hline Thanjavur & $29.1 \%$ & 24. & $36.3 \%$ & $22.8 \%$ & 24 & $31.9 \%$ & $22.5 \%$ & $7 \%$ & $27.9 \%$ & $27.2 \%$ & $3 \%$ & $31.9 \%$ \\
\hline Th & $5.7 \%$ & $9.2 \%$ & 13 & $16 \%$ & $5.2 \%$ & $13.6 \%$ & $.8 \%$ & $24.7 \%$ & $8.7 \%$ & $13.6 \%$ & $50.8 \%$ & $50.8 \%$ \\
\hline Theni & $5 \%$ & $50 \%$ & 18 & $31.9 \%$ & $53.7 \%$ & $3 \%$ & $1.8 \%$ & $3 \%$ & $8 \%$ & $6 \%$ & $7 \%$ & $4 \%$ \\
\hline Thiru & $32.6 \%$ & $30.1 \%$ & 44 & $32.6 \%$ & $20.1 \%$ & $42.3 \%$ & $3 \%$ & $.8 \%$ & $31 \%$ & $4 \%$ & $5 \%$ & $4 \%$ \\
\hline Thiruvarur & $22.8 \%$ & $19.7 \%$ & $22.8 \%$ & $17.3 \%$ & $34.7 \%$ & $.3 \%$ & $18.2 \%$ & $21.5 \%$ & $31.9 \%$ & $25 \%$ & $10.1 \%$ & \\
\hline Thoothukudi & $38.6 \%$ & $37.9 \%$ & $34.9 \%$ & $51.7 \%$ & $34.4 \%$ & $13.6 \%$ & $36.3 \%$ & $42.5 \%$ & $41.4 \%$ & $36.8 \%$ & $42.3 \%$ & $13.6 \%$ \\
\hline Tirunelveli & $48.1 \%$ & $37.7 \%$ & $41.2 \%$ & $44.4 \%$ & $50 \%$ & $48.3 \%$ & $36.7 \%$ & $46.7 \%$ & $42.8 \%$ & $52.1 \%$ & $49.2 \%$ & $27.2 \%$ \\
\hline Tirupathur & $25.2 \%$ & $30.3 \%$ & $9.2 \%$ & $31.9 \%$ & $50.8 \%$ & $21.8 \%$ & $19 \%$ & $37.7 \%$ & $20 \%$ & $11.2 \%$ & $31.9 \%$ & $28.4 \%$ \\
\hline Tiruppur & $26.4 \%$ & $23.3 \%$ & $19.2 \%$ & $26.8 \%$ & $23.1 \%$ & $14.1 \%$ & $15.5 \%$ & $18.2 \%$ & $17.5 \%$ & $19.5 \%$ & $12.5 \%$ & $6.8 \%$ \\
\hline Tiruvallur & $42.6 \%$ & $31.9 \%$ & $24.7 \%$ & $24.1 \%$ & $36.5 \%$ & $22.8 \%$ & $38.9 \%$ & $39.8 \%$ & $30.5 \%$ & $31.7 \%$ & $28.7 \%$ & $47.2 \%$ \\
\hline Tiruvannar & $31.2 \%$ & $37 \%$ & $44.9 \%$ & $37.2 \%$ & $35.8 \%$ & $48.3 \%$ & $39.7 \%$ & $35.4 \%$ & $35.1 \%$ & $30.3 \%$ & $36.1 \%$ & $17.1 \%$ \\
\hline Vellore & $37.4 \%$ & $9.4 \%$ & $29.6 \%$ & $10.5 \%$ & $28.9 \%$ & $23.8 \%$ & $29.6 \%$ & $38.8 \%$ & $35.4 \%$ & $34.4 \%$ & $14.3 \%$ & $26.8 \%$ \\
\hline Villupuram & $3 \%$ & $28.7 \%$ & $16.8 \%$ & $33.1 \%$ & $22.8 \%$ & $40.5 \%$ & $36 \%$ & $36.8 \%$ & $41.6 \%$ & $31.9 \%$ & $45.6 \%$ & $36.5 \%$ \\
\hline Virudhunagar & $30.8 \%$ & $45.8 \%$ & $35.4 \%$ & $48.5 \%$ & $21.9 \%$ & $33.3 \%$ & $34.4 \%$ & $41.6 \%$ & $47.4 \%$ & $41.6 \%$ & $30.3 \%$ & $33.7 \%$ \\
\hline
\end{tabular}


medRxiv preprint doi: https://doi.org/10.1101/2021.11.14.21265758; this version posted November 15, 2021. The copyright holder for this preprint (which was not certified by peer review) is the author/funder, who has granted medRxiv a license to display the preprint in perpetuity.

It is made available under a CC-BY 4.0 International license .

Table S 6. Seroprevalence by district and demographic group in Round 2 (April 2021).

\begin{tabular}{|c|c|c|c|c|c|c|c|c|c|c|c|c|}
\hline \multirow{2}{*}{ District } & \multicolumn{6}{|c|}{ Male } & \multicolumn{6}{|c|}{ Female } \\
\hline & $18-29$ & $30-39$ & $40-49$ & $50-59$ & $60-69$ & $70+$ & $18-29$ & $30-39$ & $40-49$ & $50-59$ & $60-69$ & $70+$ \\
\hline Ariyalur & $50 \%$ & $20.2 \%$ & $27.9 \%$ & $19.3 \%$ & $24.3 \%$ & $20.7 \%$ & $3 \%$ & $6.4 \%$ & $7.2 \%$ & $8.1 \%$ & $9.2 \%$ & $50 \%$ \\
\hline Chengalpattu & $41.2 \%$ & $41.4 \%$ & $36.8 \%$ & $37 \%$ & $32.4 \%$ & $35.8 \%$ & $31.4 \%$ & $46 \%$ & $56 \%$ & $53.5 \%$ & $33.3 \%$ & $47.2 \%$ \\
\hline Coimbatore & $28.7 \%$ & $11.4 \%$ & $24.7 \%$ & $19.5 \%$ & $11.4 \%$ & $15.1 \%$ & $18 \%$ & $17.1 \%$ & $21.4 \%$ & $25.2 \%$ & $18.2 \%$ & $12.7 \%$ \\
\hline Cuddalore & $4.3 \%$ & $12.8 \%$ & $4.3 \%$ & $21.1 \%$ & $15 \%$ & $22.8 \%$ & $8.9 \%$ & $11.4 \%$ & $15.5 \%$ & $19.5 \%$ & $20.9 \%$ & $8.3 \%$ \\
\hline Dharmapuri & $21.6 \%$ & $16.5 \%$ & $26.6 \%$ & $21.1 \%$ & $20.3 \%$ & $18.6 \%$ & $31.4 \%$ & $31.4 \%$ & $38.1 \%$ & $21.2 \%$ & $8.5 \%$ & $9.2 \%$ \\
\hline Dindigul & $0 \%$ & $14.3 \%$ & $5.6 \%$ & $15 \%$ & $11.9 \%$ & $7.1 \%$ & $14.3 \%$ & $15.6 \%$ & $16.6 \%$ & $14.5 \%$ & $19.7 \%$ & $16.3 \%$ \\
\hline Erode & $7.4 \%$ & $10.7 \%$ & $9 \%$ & $19.9 \%$ & $7.8 \%$ & $14.8 \%$ & $17.8 \%$ & $18 \%$ & $18.7 \%$ & $20.9 \%$ & $18.2 \%$ & $23.6 \%$ \\
\hline Kallakurichi & $16 \%$ & $8.6 \%$ & $8.7 \%$ & $10.1 \%$ & $3.2 \%$ & $5.7 \%$ & $9.7 \%$ & $5 \%$ & $16.2 \%$ & $20.1 \%$ & $10.3 \%$ & $15.7 \%$ \\
\hline Kancheepuram & $40 \%$ & $34.5 \%$ & $35.2 \%$ & $10.3 \%$ & $24.7 \%$ & $44.9 \%$ & $27.5 \%$ & $49 \%$ & $39.8 \%$ & $37.7 \%$ & $38.9 \%$ & $50.8 \%$ \\
\hline Kanniyakumari & $18 \%$ & $22.8 \%$ & $13.6 \%$ & $20.7 \%$ & $35.6 \%$ & $28.2 \%$ & $17.3 \%$ & $17.5 \%$ & $17.9 \%$ & $21.5 \%$ & $16.2 \%$ & $31.9 \%$ \\
\hline Karur & $24.3 \%$ & $4.6 \%$ & $8.3 \%$ & $17.3 \%$ & $17.3 \%$ & $8.6 \%$ & $2.8 \%$ & $7 \%$ & $15.1 \%$ & $15 \%$ & $15.9 \%$ & $7.2 \%$ \\
\hline Krishnagiri & $19.9 \%$ & $23.1 \%$ & $25.4 \%$ & $28.2 \%$ & $22.8 \%$ & $9.2 \%$ & $16 \%$ & $25.9 \%$ & $33.3 \%$ & $47.9 \%$ & $11.8 \%$ & $50.8 \%$ \\
\hline Madurai & $14.3 \%$ & $13.6 \%$ & $18.2 \%$ & $12.5 \%$ & $32.8 \%$ & $27 \%$ & $9.7 \%$ & $11.5 \%$ & $12.9 \%$ & $23.4 \%$ & $14.3 \%$ & $17.3 \%$ \\
\hline Nagapatti & $7 \%$ & $6.3 \%$ & $16.7 \%$ & $16.6 \%$ & $6.1 \%$ & $2.8 \%$ & $6.5 \%$ & $5.6 \%$ & $5.7 \%$ & $4 \%$ & $2 \%$ & $8.3 \%$ \\
\hline Namakkal & $19.2 \%$ & $22.8 \%$ & $23.6 \%$ & $24.1 \%$ & $31.9 \%$ & $8.2 \%$ & $24 \%$ & $26.1 \%$ & $32.8 \%$ & $31.6 \%$ & $27.5 \%$ & $22.4 \%$ \\
\hline Perambalur & $22.8 \%$ & $39.1 \%$ & $45.8 \%$ & $18.2 \%$ & $28.2 \%$ & $31.9 \%$ & $15.3 \%$ & $19.7 \%$ & $19.7 \%$ & $23.8 \%$ & $57.8 \%$ & $17.3 \%$ \\
\hline Pudukkottai & $18.4 \%$ & $22.1 \%$ & $10.1 \%$ & $7.2 \%$ & $15 \%$ & $33.7 \%$ & $7.6 \%$ & $11.5 \%$ & $10.8 \%$ & $30.5 \%$ & $23.4 \%$ & $9.2 \%$ \\
\hline Ramanathap & $2 \%$ & $16.2 \%$ & $18.7 \%$ & $10.4 \%$ & $3 \%$ & $8.3 \%$ & $0 \%$ & $7.9 \%$ & $5.6 \%$ & $20.7 \%$ & $4.6 \%$ & $11.1 \%$ \\
\hline Ranipet & $40.4 \%$ & $17.7 \%$ & $33.3 \%$ & $24.7 \%$ & $61.1 \%$ & $13.6 \%$ & $32.6 \%$ & $48.6 \%$ & $44.9 \%$ & $36.1 \%$ & $40.4 \%$ & $50.8 \%$ \\
\hline Salem & $20 \%$ & $34.9 \%$ & $21.9 \%$ & $42.3 \%$ & $19.5 \%$ & $26.1 \%$ & $20.9 \%$ & $29.8 \%$ & $30.8 \%$ & $40.5 \%$ & $28.9 \%$ & $22.8 \%$ \\
\hline Sivagangai & $6.4 \%$ & $13.6 \%$ & $5.2 \%$ & $14.5 \%$ & $1.6 \%$ & $0 \%$ & $10.3 \%$ & $7.8 \%$ & $11.1 \%$ & $11.1 \%$ & $14.9 \%$ & $13.6 \%$ \\
\hline Tenkasi & $9.7 \%$ & $9.6 \%$ & $20.1 \%$ & $14.1 \%$ & $18.8 \%$ & $24.6 \%$ & $1.7 \%$ & $16.8 \%$ & $18.1 \%$ & $32.8 \%$ & $28.9 \%$ & $21.1 \%$ \\
\hline Thanjavur & $8.2 \%$ & $12.2 \%$ & $15 \%$ & $16.5 \%$ & $20.9 \%$ & $18.7 \%$ & $11.9 \%$ & $4.6 \%$ & $11.6 \%$ & $10 \%$ & $17.3 \%$ & $13.6 \%$ \\
\hline The Nilgiris & $8.6 \%$ & $4.8 \%$ & $3.7 \%$ & $29.6 \%$ & $41.6 \%$ & $22.8 \%$ & $24.7 \%$ & $12.3 \%$ & $17.1 \%$ & $43.9 \%$ & $24.7 \%$ & $46 \%$ \\
\hline Then & $26.1 \%$ & $14.4 \%$ & $25.6 \%$ & $17.3 \%$ & $26.6 \%$ & $63.8 \%$ & $13.6 \%$ & $14.5 \%$ & $10.1 \%$ & $26.6 \%$ & $4.6 \%$ & $35.6 \%$ \\
\hline Thiruch & $14.6 \%$ & $11.1 \%$ & $5.9 \%$ & $19.2 \%$ & $14.3 \%$ & $29.3 \%$ & $23.8 \%$ & $12.2 \%$ & $16.4 \%$ & $23.8 \%$ & $24.3 \%$ & $30 \%$ \\
\hline Thiruvarur & $18 \%$ & $12.8 \%$ & $0 \%$ & $16.6 \%$ & $14.4 \%$ & $50 \%$ & $11.9 \%$ & $9 \%$ & $15.8 \%$ & $7.9 \%$ & $.9 \%$ & $7.6 \%$ \\
\hline Thoothukudi & $24.4 \%$ & $6.4 \%$ & $10.4 \%$ & $14.5 \%$ & $13.6 \%$ & $40.9 \%$ & $12.3 \%$ & $22.4 \%$ & $18.4 \%$ & $31.9 \%$ & $17.9 \%$ & $34 \%$ \\
\hline Tirunelveli & $28.2 \%$ & $20.4 \%$ & $19.7 \%$ & $14.4 \%$ & $18.2 \%$ & $39.1 \%$ & $11.1 \%$ & $13.3 \%$ & $25.9 \%$ & $24 \%$ & $26.6 \%$ & $20.9 \%$ \\
\hline Tirupathur & $31.9 \%$ & $23.4 \%$ & $34.2 \%$ & $41.1 \%$ & $40.4 \%$ & $10.3 \%$ & $16 \%$ & $28.2 \%$ & $25.9 \%$ & $26.4 \%$ & $26.3 \%$ & $17.7 \%$ \\
\hline Tiruppur & $10.1 \%$ & $28.4 \%$ & $16.5 \%$ & $27.7 \%$ & $25.2 \%$ & $5.4 \%$ & $20.2 \%$ & $29.1 \%$ & $23 \%$ & $28.2 \%$ & $22.4 \%$ & $18.5 \%$ \\
\hline Tiruvallur & $51.7 \%$ & $54.1 \%$ & $52.6 \%$ & $53.7 \%$ & $42.1 \%$ & $26.1 \%$ & $49 \%$ & $49.3 \%$ & $50 \%$ & $54.1 \%$ & $49.5 \%$ & $39.5 \%$ \\
\hline Tiruvannamalai & $43.7 \%$ & $31.7 \%$ & $25.7 \%$ & $38.1 \%$ & $43.2 \%$ & $18 \%$ & $31.2 \%$ & $27.2 \%$ & $32.1 \%$ & $47.2 \%$ & $36 \%$ & $36.5 \%$ \\
\hline Vellore & $35.1 \%$ & $38.4 \%$ & $28.9 \%$ & $33.3 \%$ & $29.3 \%$ & $28.4 \%$ & $34 \%$ & $39.8 \%$ & $36.3 \%$ & $27.7 \%$ & $43 \%$ & $28.4 \%$ \\
\hline Villupuram & $5.2 \%$ & $17.8 \%$ & $12.8 \%$ & $7.6 \%$ & $18.5 \%$ & $8.6 \%$ & $12.2 \%$ & $12.6 \%$ & $18 \%$ & $14.3 \%$ & $11.1 \%$ & $16.5 \%$ \\
\hline Virudhunagar & $6.7 \%$ & $21.1 \%$ & $22.8 \%$ & $12.3 \%$ & $38.6 \%$ & $37.9 \%$ & $13.6 \%$ & $7.9 \%$ & $23.1 \%$ & $26.4 \%$ & $30 \%$ & $18.7 \%$ \\
\hline
\end{tabular}

Note. Chennai district was not included in sampling during round 2. 
medRxiv preprint doi: https://doi.org/10.1101/2021.11.14.21265758; this version posted November 15, 2021. The copyright holder for this preprint (which was not certified by peer review) is the author/funder, who has granted medRxiv a license to display the preprint in perpetuity.

It is made available under a CC-BY 4.0 International license .

Table S 7. Seroprevalence by district and demographic group in Round 3 (June-July 2021).

\begin{tabular}{|c|c|c|c|c|c|c|c|c|c|c|c|c|}
\hline \multirow{2}{*}{ District } & \multicolumn{6}{|c|}{ Male } & \multicolumn{6}{|c|}{ Female } \\
\hline & $18-29$ & $30-39$ & $40-49$ & $50-59$ & $60-69$ & $70+$ & $18-29$ & $30-39$ & $40-49$ & $50-59$ & $60-69$ & $70+$ \\
\hline Ariyalur & $58.7 \%$ & $73.5 \%$ & $36.5 \%$ & $63.8 \%$ & $57.8 \%$ & $22.8 \%$ & $54.7 \%$ & $59.6 \%$ & $58.4 \%$ & $53.5 \%$ & $62 \%$ & $80.4 \%$ \\
\hline Chengalpattu & $59.2 \%$ & $68.4 \%$ & $68 \%$ & $60.1 \%$ & $61.6 \%$ & $64.7 \%$ & $64.8 \%$ & $71.2 \%$ & $76.5 \%$ & $62.9 \%$ & $54.4 \%$ & $93.3 \%$ \\
\hline Chennai & $87.1 \%$ & $75.7 \%$ & $80.1 \%$ & $81.8 \%$ & $80.1 \%$ & $85.2 \%$ & $87 \%$ & $85.2 \%$ & $86.5 \%$ & $88.3 \%$ & $82.3 \%$ & $87.5 \%$ \\
\hline Coimbatore & $41.4 \%$ & $43.2 \%$ & $37.4 \%$ & $36.3 \%$ & $42.5 \%$ & $35.4 \%$ & $51.7 \%$ & $50 \%$ & $49.2 \%$ & $48.3 \%$ & $38.1 \%$ & $46.3 \%$ \\
\hline Cuddalore & $84.2 \%$ & $77.3 \%$ & $72.7 \%$ & $69.9 \%$ & $76.8 \%$ & $60 \%$ & $71.6 \%$ & $71.3 \%$ & $66 \%$ & $65.3 \%$ & $76.8 \%$ & $68.3 \%$ \\
\hline Dharmapuri & $64.7 \%$ & $63.8 \%$ & $55 \%$ & $45.5 \%$ & $50.8 \%$ & $60 \%$ & $61.1 \%$ & $67.6 \%$ & $68.5 \%$ & $68 \%$ & $62.8 \%$ & $65.6 \%$ \\
\hline Dindigul & $82.4 \%$ & $75.3 \%$ & $68.9 \%$ & $78.2 \%$ & $69.9 \%$ & $47.2 \%$ & $76.7 \%$ & $81 \%$ & $73.5 \%$ & $71.6 \%$ & $78.8 \%$ & $63.8 \%$ \\
\hline Erode & $40.4 \%$ & $39.7 \%$ & $39.1 \%$ & $34.7 \%$ & $34.4 \%$ & $28.4 \%$ & $38.9 \%$ & $36.3 \%$ & $42.3 \%$ & $39.1 \%$ & $29.3 \%$ & $35.4 \%$ \\
\hline Kallakurichi & $67.6 \%$ & $60.2 \%$ & $76.5 \%$ & $75.3 \%$ & $56.9 \%$ & $62.6 \%$ & $76.9 \%$ & $79.9 \%$ & $67.5 \%$ & $66.9 \%$ & $74.9 \%$ & 7 \\
\hline Kancheepuram & $62.5 \%$ & $54.6 \%$ & $75.9 \%$ & $83.8 \%$ & $50.8 \%$ & $50.8 \%$ & $73.6 \%$ & $62.5 \%$ & $77.7 \%$ & $62.3 \%$ & $50.8 \%$ & \\
\hline Kanniyakumari & $77.3 \%$ & $78.7 \%$ & $77.9 \%$ & $61 \%$ & $83.4 \%$ & $68.3 \%$ & $68.9 \%$ & $67 \%$ & $75.4 \%$ & $83 \%$ & $67 \%$ & $77.3 \%$ \\
\hline Karur & $52.4 \%$ & $64.9 \%$ & $52.1 \%$ & $54.6 \%$ & $45.8 \%$ & $36.5 \%$ & $41.6 \%$ & $54.1 \%$ & $57.8 \%$ & $61 \%$ & $45.1 \%$ & $56.6 \%$ \\
\hline Krishnagiri & $69.8 \%$ & $58.6 \%$ & $48.6 \%$ & $57.8 \%$ & $62.8 \%$ & $61.1 \%$ & $57.9 \%$ & $65.2 \%$ & $63.3 \%$ & $59.2 \%$ & $72.6 \%$ & $61.1 \%$ \\
\hline Madurai & $81 \%$ & $74.1 \%$ & $84.2 \%$ & $86.1 \%$ & $72.3 \%$ & $76.2 \%$ & $80.8 \%$ & $79.6 \%$ & $87.5 \%$ & $82.2 \%$ & $81.4 \%$ & $85.3 \%$ \\
\hline Nagapattinam & $61 \%$ & $57.8 \%$ & $51.4 \%$ & $64.4 \%$ & $47.6 \%$ & $37.5 \%$ & $51.8 \%$ & $61.5 \%$ & $52.3 \%$ & $62.6 \%$ & $60.3 \%$ & $29.6 \%$ \\
\hline Namakkal & $57.5 \%$ & $60.5 \%$ & $50.8 \%$ & $49.7 \%$ & $65.2 \%$ & $50.8 \%$ & $1.8 \%$ & $44.4 \%$ & $51.4 \%$ & $46 \%$ & $37.9 \%$ & $27.7 \%$ \\
\hline Perambalur & $47.9 \%$ & $61 \%$ & $50 \%$ & $43.9 \%$ & $43.9 \%$ & $31.9 \%$ & $79.5 \%$ & $79.5 \%$ & $45.6 \%$ & $64.9 \%$ & $70.2 \%$ & $43.9 \%$ \\
\hline Pudukkottai & $70.3 \%$ & $61 \%$ & $63.2 \%$ & $70.7 \%$ & $48.5 \%$ & $37.5 \%$ & $70.2 \%$ & $72.2 \%$ & $64.9 \%$ & $58.2 \%$ & $80.8 \%$ & $57.8 \%$ \\
\hline Ramanathapuram & $73.5 \%$ & $80.1 \%$ & $67.4 \%$ & $78.2 \%$ & $69.4 \%$ & $72.6 \%$ & $81.3 \%$ & $78.7 \%$ & $85.1 \%$ & $81.9 \%$ & $82.8 \%$ & $26.6 \%$ \\
\hline Ranipet & $56 \%$ & $69.9 \%$ & $78.5 \%$ & $68 \%$ & $79.6 \%$ & $66.6 \%$ & $76.8 \%$ & $65.6 \%$ & $68.8 \%$ & $81.5 \%$ & $86.7 \%$ & $50.8 \%$ \\
\hline Salem & $66.6 \%$ & $60.1 \%$ & $63.8 \%$ & $65.2 \%$ & $62.5 \%$ & $53.7 \%$ & $60.1 \%$ & $64 \%$ & $60.3 \%$ & $63.8 \%$ & $61 \%$ & $33.3 \%$ \\
\hline Sivagangai & $64.9 \%$ & $64.7 \%$ & $57.8 \%$ & $68.3 \%$ & $66 \%$ & $56.9 \%$ & $70.7 \%$ & $54.6 \%$ & $79.1 \%$ & $59.7 \%$ & $63.8 \%$ & $43.9 \%$ \\
\hline Tenkasi & $86.5 \%$ & $78.7 \%$ & $66.6 \%$ & $77.3 \%$ & $73.5 \%$ & $68.3 \%$ & $88.3 \%$ & $78.8 \%$ & $93.5 \%$ & $81.5 \%$ & $71.8 \%$ & $50 \%$ \\
\hline Thanjavur & $63.2 \%$ & $62.9 \%$ & $63.8 \%$ & $72.2 \%$ & $72.6 \%$ & $50 \%$ & $58.3 \%$ & $63.8 \%$ & $70.9 \%$ & $59.2 \%$ & $53.1 \%$ & $37 \%$ \\
\hline The Nilgiris & $35.4 \%$ & $33.3 \%$ & $48.6 \%$ & $75 \%$ & $75.4 \%$ & $83.8 \%$ & $48.6 \%$ & $50.8 \%$ & $65.8 \%$ & $61.1 \%$ & $53.5 \%$ & $68 \%$ \\
\hline Theni & $86.5 \%$ & $78.7 \%$ & $79 \%$ & $61 \%$ & $75.5 \%$ & $56.1 \%$ & $88.3 \%$ & $87.4 \%$ & $70.9 \%$ & $83.8 \%$ & $79.5 \%$ & $80.4 \%$ \\
\hline Thiruchirap & $77.3 \%$ & $65.7 \%$ & $64.8 \%$ & $67.7 \%$ & $78.8 \%$ & $50 \%$ & $67.7 \%$ & $69.9 \%$ & $67.2 \%$ & $69.4 \%$ & $67.2 \%$ & $53.2 \%$ \\
\hline Thiruvarur & $68.3 \%$ & $65.2 \%$ & $77.9 \%$ & $56.4 \%$ & $36.5 \%$ & $62.6 \%$ & $68.3 \%$ & $62.5 \%$ & $65.2 \%$ & $46.2 \%$ & $82.8 \%$ & $31.9 \%$ \\
\hline Thoothukudi & $72.2 \%$ & $77.3 \%$ & $76.2 \%$ & $78.1 \%$ & $74.5 \%$ & $75.3 \%$ & $71.6 \%$ & $75.8 \%$ & $81.3 \%$ & $75.7 \%$ & $78.2 \%$ & $58.7 \%$ \\
\hline Tirunelveli & $89 \%$ & $80.4 \%$ & $78.1 \%$ & $72.2 \%$ & $68.3 \%$ & $84.7 \%$ & $79.2 \%$ & $72.7 \%$ & $77.3 \%$ & $88.2 \%$ & $82.4 \%$ & $64.9 \%$ \\
\hline Tirupathur & $58.2 \%$ & $72.5 \%$ & $69.1 \%$ & $55.5 \%$ & $44.9 \%$ & $33.3 \%$ & $63.4 \%$ & $62.3 \%$ & $58.7 \%$ & $75.8 \%$ & $46 \%$ & $40.4 \%$ \\
\hline Tiruppur & $51.4 \%$ & $41.1 \%$ & $46.9 \%$ & $52.7 \%$ & $50.8 \%$ & $32.4 \%$ & $44.4 \%$ & $53.1 \%$ & $39.5 \%$ & $49.2 \%$ & $49 \%$ & $47.9 \%$ \\
\hline Tiruvallur & $54.1 \%$ & $62 \%$ & $60.9 \%$ & $60.9 \%$ & $64.3 \%$ & $56.5 \%$ & $70.4 \%$ & $76.3 \%$ & $74 \%$ & $77.7 \%$ & $67.4 \%$ & $70.3 \%$ \\
\hline Tiruvannamalai & $78.7 \%$ & $64.4 \%$ & $68 \%$ & $59.1 \%$ & $65.6 \%$ & $56.9 \%$ & $62.5 \%$ & $69.9 \%$ & $71.6 \%$ & $83.4 \%$ & $73.6 \%$ & $69 \%$ \\
\hline Vellore & $69 \%$ & $76.8 \%$ & $71.2 \%$ & $59.2 \%$ & $55.6 \%$ & $56.9 \%$ & $71.7 \%$ & $68.3 \%$ & $68.3 \%$ & $74 \%$ & $76.3 \%$ & $66.2 \%$ \\
\hline Villupuram & $78.5 \%$ & $67.1 \%$ & $62.1 \%$ & $68.9 \%$ & $50 \%$ & $63.4 \%$ & $71.4 \%$ & $68.5 \%$ & $61.5 \%$ & $58.2 \%$ & $69.5 \%$ & $75.3 \%$ \\
\hline Virudhunagar & $89.6 \%$ & $83.2 \%$ & $87.9 \%$ & $84.8 \%$ & $92.2 \%$ & $59.1 \%$ & $86.7 \%$ & $92.2 \%$ & $86.7 \%$ & $92.1 \%$ & $77.9 \%$ & $74.9 \%$ \\
\hline
\end{tabular}




\section{References}

1. Wikipedia. List of states and union territories of India by population. 2020.

https://en.wikipedia.org/wiki/List_of states and union territories of India_by population (accessed January 4, 2021 2021).

2. Government of India. mygov.in: \#IndiaFightsCorona COVID-19. 2021.

https://www.mygov.in/covid-19.

3. Kish L. A Procedure for Objective Respondent Selection within the Household. Journal of the American Statistical Association 1949; 44(247): 380-7.

4. Shenzhen YHLO Biotech Co. Ltd. Customer Notification: Sensitivity and Specificity of iFlash-SARS-Cov-2 IgG and IgM kits from Clinical Trials 2020.

5. Ortho Clinical Diagnostics. INSTRUCTIONS FOR USE - CoV2G (Version 4.2), 2020.

6. World Health Organization. COVID-19 Weekly Epidemiological Update. 2021.

7. World Health Organization. Tracking SARS-CoV-2 variants. 2021.

https://www.who.int/en/activities/tracking-SARS-CoV-2-variants/.

8. Post N, Eddy D, Huntley $\mathrm{C}$, et al. Antibody response to SARS-CoV-2 infection in humans: A systematic review. PLOS ONE 2021; 15(12): e0244126.

9. Plebani M, Padoan A, Negrini D, Carpinteri B, Sciacovelli L. Diagnostic performances and thresholds: The key to harmonization in serological SARS-CoV-2 assays? Clinica Chimica Acta 2020; 509: 1-7.

10. U.S. Food and Drug Administration. Serology Test Evaluation Report for "VITROS Immunodiagnostic Products Anti-SARS-CoV-2 IgG Reagent Pack" from Ortho-Clinical Diagnostics, Inc., 2020.

11. Theel ES, Harring J, Hilgart H, Granger D. Performance Characteristics of Four HighThroughput Immunoassays for Detection of IgG Antibodies against SARS-CoV-2. Journal of Clinical Microbiology 2020; 58(8): e01243-20. 